\title{
OCEANIC RADIOCARBON BETWEEN ANTARCTICA AND SOUTH AFRICA ALONG WOCE SECTION 16 AT $30^{\circ} \mathrm{E}$
}

\author{
Viviane Leboucher ${ }^{1} \bullet$ James Orr $^{2} \bullet$ Philippe Jean-Baptiste $^{2} \bullet$ Maurice Arnold $^{1} \bullet$ Patrick Monfray $^{1}$ \\ Nadine Tisnerat-Laborde ${ }^{1}$ Alain Poisson ${ }^{3} \bullet$ Jean-Claude Duplessy ${ }^{1}$
}

\begin{abstract}
Accelerator mass spectrometry (AMS) radiocarbon measurements were made on 120 samples collected between Antarctica and South Africa along $30^{\circ} \mathrm{E}$ during the WOCE-France CIVA1 campaign in February 1993. Our principal objective was to complement the Southern Ocean's sparse existing data set in order to improve the ${ }^{14} \mathrm{C}$ benchmark used for validating ocean carbon-cycle models, which disagree considerably in this region. Measured ${ }^{14} \mathrm{C}$ is consistent with the $\theta-\mathrm{S}$ characteristics of CIVA1. Antarctic Intermediate Water (AAIW) forming north of the Polar Front (PF) is rich in ${ }^{14} \mathrm{C}$, whereas surface waters south of the PF are depleted in ${ }^{14} \mathrm{C}$. A distinct old ${ }^{14} \mathrm{C}$ signal was found for the contribution of the Pacific Deep Water (PDW) to the return flow of Circumpolar Deep Waters (CDW). Comparison to previous measurements shows a ${ }^{14} \mathrm{C}$ decrease in surface waters, consistent with northward displacement of surface waters, replacement by old deep waters upwelled at the Antarctic Divergence, and atmospheric decline in ${ }^{14} \mathrm{C}$. Conversely, an increase was found in deeper layers, in the AAIW. Large uncertainties, associated with previous methods for separating natural and bomb ${ }^{14} \mathrm{C}$ when in the Southern Ocean south of $45^{\circ} \mathrm{S}$, motivated us to develop a new approach that relies on a simple mixing model and on chlorofluorocarbon (CFC) measurements also taken during CIVA1. This approach leads to inventories for CIVA1 that are equal to or higher than those calculated with previous methods. Differences between old and new methods are especially high south of approximately $55^{\circ} \mathrm{S}$, where bomb ${ }^{14} \mathrm{C}$ inventories are relatively modest.
\end{abstract}

\section{INTRODUCTION}

The Southern Ocean extends south to Antarctica and north to the Subtropical Front (STF), which meanders between $40^{\circ} \mathrm{S}$ and $50^{\circ} \mathrm{S}$. As such, the Southern Ocean covers about $21 \%$ of the world's ocean surface. Within the Southern Ocean, large vertical exchanges take place between water masses. Important processes include ventilation of deep waters at the Antarctic Divergence Zone (ADZ, ca. $65^{\circ} \mathrm{S}$ ), production of ventilated bottom waters in the Weddell Sea and around the Antarctic continental slope, and formation of Antarctic Intermediate Water (AAIW) within the Polar Frontal Zone (PFZ) between the Polar Front (PF) and the Subantarctic Front (SAF).

The Southern Ocean is considered to be a major sink for anthropogenic $\mathrm{CO}_{2}$ (Sarmiento et al. 1992). However, for this region, there is substantial disagreement between carbon-cycle simulations from different ocean general circulation models (OGCMs), which offer the only means to estimate future oceanic $\mathrm{CO}_{2}$ uptake (Orr 1996). Radiocarbon is routinely used to evaluate the performance of such models (Toggweiler et al. 1989a, 1989b; Maier-Reimer 1993; Taylor 1995; Orr 1996). However, few ${ }^{14} \mathrm{C}$ data are available in the remote Southern Ocean, where both the spatial and temporal changes in ${ }^{14} \mathrm{C}$ are important. Here, we provide ${ }^{14} \mathrm{C}$ data to complement the sparse established dataset. Previous ${ }^{14} \mathrm{C}$ measurements include those from GEOSECS (Geochemical Ocean Sections Study) during 1973-1978 (Östlund and Stuiver 1980; Stuiver and Östlund 1980; Stuiver et al. 1981), from the Winter Weddell Sea Experiment (WWSP) in 1986 (Schlosser et al. 1994), and from INDIGO (Indian Gas Ocean project) in 1985-1987 (Östlund and Grall 1988). The ${ }^{14} \mathrm{C}$ data presented here were collected during CIVA1 (Circulation et Ventilation dans l'Antarctique) of WOCE-France taken in FebruaryMarch 1993. Measurements of ${ }^{14} \mathrm{C}$ were made by AMS in Gif-sur-Yvette, France.

\footnotetext{
'Laboratoire des Sciences du Climat et de l'Environnement (LSCE), Avenue de la Terrasse, F-91198 Gif-sur-Yvette Cedex, France

${ }^{2}$ Laboratoire des Sciences du Climat et de l'Environnement (LSCE), DSM/CEN Saclay/CEA, L'Orme, Bât. 709, F-91191 Gif-sur-Yvette Cedex, France

${ }^{3}$ Laboratoire de Physique et Chimie Marines (LPCM), Université Pierre et Marie Curie, 4, place Jussieu, F-75252 Paris Cedex 05, France
} 
Oceanic ${ }^{14} \mathrm{C}$ must be separated into its natural and anthropogenic components if it is to be useful for model validation. Natural ${ }^{14} \mathrm{C}$ is produced by cosmic radiation and can be considered at present to be in steady state with respect to the vertical turnover time of the ocean (ca. $1000 \mathrm{yr}$ ). Bomb ${ }^{14} \mathrm{C}$ was injected in the atmosphere nearly exclusively by atmospheric thermonuclear weapons tests during the 1950s and 1960s. At its peak in 1963, the nuclear contribution nearly doubled prenuclear atmospheric levels of ${ }^{14} \mathrm{C}$. Since then, atmospheric ${ }^{14} \mathrm{C}$ has decreased. At present, levels are roughly $10 \%$ higher than in the prenuclear period. Both ${ }^{14} \mathrm{C}$ components are transferred to the ocean by air-sea gas exchange as ${ }^{14} \mathrm{CO}_{2}$. With its steady-state production and $5730 \mathrm{yr}$ half-life, the natural component of ${ }^{14} \mathrm{C}$ is useful for evaluating modeled deep-ocean circulation fields. Bomb ${ }^{14} \mathrm{C}$ has had much less time to invade the ocean. Because its boundary conditions have changed rapidly since the late 1950 s, bomb ${ }^{14} \mathrm{C}$ is useful for evaluating near-surface circulation fields predicted by ocean models.

To separate natural and bomb ${ }^{14} \mathrm{C}$, we first applied the method developed by Broecker et al. (1995), which relies on the near linear correlation between natural $\Delta^{14} \mathrm{C}$ and dissolved silica throughout much of the ocean. However, for the stations situated south of $45^{\circ} \mathrm{S}(\sim 90 \%$ of samples collected here), uncertainties associated with Broecker et al.'s method are large. Since the GEOSECS campaign in the 1970s, it has become less certain that deep waters remain uncontaminated with bomb ${ }^{14} \mathrm{C}$, as supposed by Broecker et al. (1995) for GEOSECS era samples. To take this possibility into account, we modified the bomb versus natural separation methodology for our samples taken south of $45^{\circ} \mathrm{S}$. Our new method takes advantage of CFC- 11 and CFC- 12 measured during CIVA1 and uses a simple ventilation model, similar to that used in previous tracer studies (Jenkins 1980; Andrié et al. 1986; Haine 1996).

\section{METHODS}

The ${ }^{14} \mathrm{C}$ data (Table 1) were obtained following the procedure described by Bard et al. (1987) and Arnold et al. (1987). Seawater was collected in 12-L Niskins. Once aboard ship, seawater was transferred to $250 \mathrm{~mL}$ borosilicate bottles and poisoned with $1 \mathrm{~mL}$ of saturated $\mathrm{HgCl}_{2}$ solution. The borosilicate bottles were then sealed. Back in the laboratory, $\mathrm{CO}_{2}$ was extracted by adding $2 \mathrm{~mL}$ of $15 \mathrm{~N}$ $\mathrm{H}_{3} \mathrm{PO}_{4}$ to a $100 \mathrm{~mL}$ seawater aliquot in a vacuum-tight system sparged by $\mathrm{He}$ gas (flow rate $80 \mathrm{~mL}$ $\left.\mathrm{min}^{-1}\right)$. Extraction required $1 \mathrm{~h}$. Water was removed by traps at $-80^{\circ} \mathrm{C} ; \mathrm{CO}_{2}$ was trapped at $-180^{\circ} \mathrm{C}$. Subsequently, $\mathrm{CO}_{2}$ was reduced to graphite using hydrogen in the presence of iron powder $(6-8 \mathrm{~h})$. The carbon-iron mixture was divided into 3 parts, then pressed into an aluminum target for accelerator mass spectrometry (AMS) analysis. Usually, 2 or 3 targets per sample were analyzed to obtain a precision close to $\pm 5 \%$. The 3 isotopes, ${ }^{12} \mathrm{C},{ }^{13} \mathrm{C}$ and ${ }^{14} \mathrm{C}$, were measured directly in the AMS system to calculate $\Delta^{14} \mathrm{C}$ normalized to a $\delta^{13} \mathrm{C}$ of $-25 \%$. The data are expressed as $\Delta{ }^{14} \mathrm{C}$ in per mil (Stuiver and Polach 1977).

\section{RESULTS}

To establish the level of agreement of our ${ }^{14} \mathrm{C}$ CIVA1 measurements with previous data, Figure 1 provides ${ }^{14} \mathrm{C}$ profiles from station 442 of GEOSECS (1978) and from station 1 of JADE1 (Java Australia Dynamic Experiment 1989$)$ cruise, both taken at the same location $\left(1^{\circ} \mathrm{S}, 91^{\circ} \mathrm{E}\right)$ in the equatorial Indian Ocean. The ${ }^{14} \mathrm{C}$ measurements from JADE1 were made in Gif-sur-Yvette by AMS just prior to those of CIVA1. JADE1 and CIVA1 samples received identical processing. The deep portions of GEOSECS and JADE1 profiles, where bomb ${ }^{14} \mathrm{C}$ has not penetrated, agree to within the precision of the measurements. Therefore, our ${ }^{14} \mathrm{C}$ measurements by AMS are consistent with those from GEOSECS, determined by $\beta$-counting. Furthermore, the methodology used at Gif-sur-Yvette has been previously checked by directly comparing $\beta$-counting and AMS measurements performed on the same samples from INDIGO (Bard et al. 1988). 
Table 1 Data for the stations occupied during the CIVA1 cruise

\begin{tabular}{|c|c|c|c|c|c|c|c|c|c|c|c|}
\hline $\begin{array}{l}\text { Depth } \\
(\mathrm{m})\end{array}$ & $\begin{array}{c}\text { Potential } \\
\text { temp. } \\
\left({ }^{\circ} \mathrm{C}\right) \\
\end{array}$ & $\begin{array}{l}\text { Salinity } \\
(\mathrm{S}, \mathrm{psu})\end{array}$ & Sig 0 & $\begin{array}{c}\mathrm{SiO}_{2} \\
\left(\mu \mathrm{mol} \mathrm{kg}{ }^{-1}\right)\end{array}$ & $\begin{array}{c}\mathrm{SCO}_{2} \\
\left(\mathrm{mmol} \mathrm{kg}^{-1}\right) \\
\end{array}$ & $\begin{array}{c}\text { CFC-11 } \\
\left(\mathrm{pmol} \mathrm{kg}^{-1}\right)\end{array}$ & $\begin{array}{c}\text { CFC-12 } \\
\left(\mathrm{pmol} \mathrm{kg}^{-1}\right)\end{array}$ & $\begin{array}{c}\text { Num. } \\
\text { of } \\
\text { meas. }\end{array}$ & $\begin{array}{l}\Delta^{14} \mathrm{C} \\
(\% \circ) \\
\end{array}$ & $\begin{array}{l}\text { Nat. } \\
\Delta^{14} \mathrm{C} \\
(\% o) \\
\end{array}$ & $\begin{array}{c}\text { Bomb } \\
\Delta^{14} \mathrm{C} \\
(\% \circ) \\
\end{array}$ \\
\hline $\begin{array}{c}\text { Station 6 } \\
10.2 \\
19.9 \\
40 \\
100.6 \\
150.5 \\
199.7 \\
324.4 \\
698.8 \\
998.8 \\
1198.8 \\
2247.1 \\
2497.6 \\
2997.6 \\
3495.9 \\
3681.3\end{array}$ & $\begin{array}{c}68^{\circ} S, 30^{\circ} \mathrm{E} \\
0.2009 \\
0.1145 \\
-0.1182 \\
-1.7636 \\
-1.6967 \\
-0.5536 \\
0.7518 \\
0.7136 \\
0.4484 \\
0.2899 \\
-0.2104 \\
-0.2729 \\
-0.378 \\
-0.4769 \\
-0.5667\end{array}$ & $\begin{array}{l}33.915 \\
33.919 \\
33.933 \\
34.35 \\
34.371 \\
34.468 \\
34.642 \\
34.693 \\
34.687 \\
34.683 \\
34.666 \\
\overline{-} \\
34.665 \\
34.655 \\
34.655\end{array}$ & $\begin{array}{l}27.218 \\
27.225 \\
27.249 \\
27.651 \\
27.665 \\
27.708 \\
27.773 \\
27.816 \\
27.829 \\
27.833 \\
27.847 \\
27.848 \\
27.851 \\
27.852 \\
27.855\end{array}$ & $\begin{array}{l}62.25 \\
62.25 \\
63.06 \\
68.77 \\
70 \\
83.5 \\
99.93 \\
115.4 \\
124.7 \\
130.9 \\
136.3 \\
135.6 \\
136.3 \\
137.1 \\
137.1\end{array}$ & $\begin{array}{l}2149 \\
2152 \\
2160 \\
2217 \\
2210 \\
2240 \\
2247 \\
2254 \\
2266 \\
2264 \\
2260 \\
2258 \\
2253 \\
2254 \\
-\end{array}$ & $\begin{array}{l}6.76 \\
6.72 \\
6.7 \\
5.68 \\
5.59 \\
3.59 \\
1.14 \\
0.58 \\
0.46 \\
0.41 \\
0.56 \\
0.64 \\
0.91 \\
1 \\
0.99\end{array}$ & $\begin{array}{l}2.92 \\
2.93 \\
2.86 \\
2.47 \\
2.45 \\
1.52 \\
0.46 \\
0.23 \\
0.18 \\
0.17 \\
0.21 \\
0.24 \\
0.36 \\
0.41 \\
0.4\end{array}$ & $\begin{array}{l}2 \\
2 \\
2 \\
2 \\
2 \\
2 \\
2 \\
2 \\
2 \\
2 \\
2 \\
2 \\
3 \\
2 \\
2\end{array}$ & $\begin{array}{r}-97 \pm 4 \\
-97 \pm 4 \\
-98 \pm 4 \\
-114 \pm 4 \\
-117 \pm 4 \\
-141 \pm 4 \\
-165 \pm 4 \\
-157 \pm 4 \\
-157 \pm 4 \\
-164 \pm 4 \\
-158 \pm 4 \\
-153 \pm 4 \\
-145 \pm 7 \\
-157 \pm 4 \\
-162 \pm 4\end{array}$ & $\begin{array}{l}-132 \\
-132 \\
-133 \\
-139 \\
-140 \\
-154 \\
-176 \\
-163 \\
-162 \\
-168 \\
-163 \\
-159 \\
-153 \\
-167 \\
-171\end{array}$ & $\begin{array}{r}35 \\
36 \\
35 \\
25 \\
23 \\
13 \\
11 \\
6 \\
5 \\
4 \\
6 \\
6 \\
9 \\
10 \\
10\end{array}$ \\
\hline $\begin{array}{c}\text { Station } 8 \\
10.6 \\
20.2 \\
40 \\
80.8 \\
124.7 \\
175.9 \\
322.1 \\
598.4 \\
795 \\
997.1 \\
1195.8 \\
1795.5 \\
2242.4 \\
2740.9 \\
3193.9 \\
3697.2 \\
4065.7 \\
4065.9\end{array}$ & $\begin{array}{c}67^{\circ} \mathrm{S}, 30^{\circ} \mathrm{E} \\
0.646 \\
0.6406 \\
-1.505 \\
-1.7041 \\
-1.142 \\
0.4412 \\
1.1479 \\
1.0146 \\
0.7838 \\
0.5854 \\
0.3901 \\
0.0023 \\
-0.1795 \\
-0.3279 \\
-0.4247 \\
-0.5206 \\
-0.6255 \\
-0.6265\end{array}$ & $\begin{array}{l}33.866 \\
33.869 \\
34.249 \\
34.356 \\
34.412 \\
34.564 \\
34.679 \\
34.708 \\
34.704 \\
34.697 \\
34.687 \\
34.672 \\
34.667 \\
34.663 \\
34.659 \\
34.656 \\
34.652 \\
34.653\end{array}$ & $\begin{array}{l}27.155 \\
27.155 \\
27.568 \\
27.653 \\
27.682 \\
27.729 \\
27.778 \\
27.812 \\
27.823 \\
27.83 \\
27.834 \\
27.841 \\
27.846 \\
27.85 \\
27.851 \\
27.853 \\
27.855 \\
27.856\end{array}$ & $\begin{array}{l}60 \\
60 \\
60.77 \\
65.5 \\
71.02 \\
86.01 \\
92.69 \\
102.5 \\
110.1 \\
115.4 \\
118.4 \\
124.8 \\
128.6 \\
127.8 \\
126.3 \\
127.1 \\
129.3 \\
130.9\end{array}$ & $\begin{array}{l}2158 \\
2164 \\
2197 \\
2216 \\
2228 \\
2255 \\
2266 \\
2263 \\
2267 \\
2250 \\
2267 \\
2270 \\
2263 \\
2260 \\
2258 \\
2260 \\
2247 \\
2253\end{array}$ & $\begin{array}{l}6.58 \\
6.57 \\
5.7 \\
5.43 \\
4.62 \\
2 \\
0.74 \\
0.39 \\
0.32 \\
0.27 \\
0.33 \\
0.53 \\
0.69 \\
0.94 \\
0.98 \\
0.91 \\
0.94\end{array}$ & $\begin{array}{l}2.89 \\
2.84 \\
2.46 \\
2.36 \\
1.95 \\
0.85 \\
0.29 \\
0.15 \\
0.13 \\
0.09 \\
0.12 \\
0.12 \\
0.28 \\
0.39 \\
0.42 \\
0.36 \\
0.36\end{array}$ & $\begin{array}{l}2 \\
2 \\
2 \\
2 \\
2 \\
2 \\
2 \\
2 \\
2 \\
2 \\
2 \\
2 \\
2 \\
3 \\
2 \\
2 \\
2 \\
2\end{array}$ & $\begin{array}{r}-97 \pm 4 \\
-97 \pm 5 \\
-104 \pm 4 \\
-103 \pm 4 \\
-111 \pm 4 \\
-130 \pm 5 \\
-155 \pm 5 \\
-148 \pm 4 \\
-179 \pm 5 \\
-175 \pm 4 \\
-154 \pm 4 \\
-154 \pm 5 \\
-154 \pm 4 \\
-166 \pm 8 \\
-160 \pm 4 \\
-167 \pm 4 \\
-150 \pm 4 \\
-154 \pm 4\end{array}$ & $\begin{array}{l}-130 \\
-130 \\
-131 \\
-136 \\
-141 \\
-156 \\
-162 \\
-152 \\
-182 \\
-175 \\
-157 \\
-159 \\
-160 \\
-173 \\
-169 \\
-176 \\
-159 \\
-163\end{array}$ & $\begin{array}{r}33 \\
33 \\
27 \\
33 \\
30 \\
26 \\
7 \\
4 \\
4 \\
0 \\
3 \\
4 \\
6 \\
7 \\
9 \\
10 \\
9 \\
9\end{array}$ \\
\hline $\begin{array}{c}\text { Station } 12 \\
10.6 \\
20.1 \\
39.4 \\
99.8 \\
149.7 \\
200.1 \\
324.5 \\
499.8 \\
698.9 \\
998 \\
1197.1 \\
2000 \\
3000 \\
4495.9\end{array}$ & $\begin{array}{c}65^{\circ} \mathrm{S}, 30^{\circ} \mathrm{E} \\
1.004 \\
1.0006 \\
0.6738 \\
-0.9583 \\
0.6731 \\
0.9763 \\
1.2006 \\
1.2749 \\
1.0755 \\
0.749 \\
0.5752 \\
- \\
-0.6169\end{array}$ & $\begin{array}{l}\text { E3.829 } \\
33.829 \\
33.842 \\
34.411 \\
34.57 \\
34.615 \\
34.675 \\
34.715 \\
34.718 \\
34.706 \\
34.699 \\
34.674 \\
34.663 \\
34.652\end{array}$ & $\begin{array}{l}27.1 \\
27.1 \\
27.15 \\
27.673 \\
27.721 \\
27.74 \\
27.772 \\
27.799 \\
27.813 \\
27.827 \\
27.831 \\
- \\
\overline{-} \\
27.856\end{array}$ & $\begin{array}{c}54.24 \\
53.44 \\
54.24 \\
70.95 \\
85.3 \\
89.28 \\
95.66 \\
102 \\
\overline{113.2} \\
116.4 \\
- \\
\overline{129} .2\end{array}$ & $\begin{array}{l}2164 \\
2155 \\
2168 \\
2225 \\
2259 \\
2261 \\
2255 \\
2264 \\
2266 \\
2257 \\
2259 \\
2264 \\
2261 \\
2253\end{array}$ & $\begin{array}{l}6.45 \\
6.44 \\
6.46 \\
4.37 \\
1.84 \\
1.29 \\
0.72 \\
0.3 \\
0.24 \\
0.2 \\
0.2 \\
0.23 \\
0.4 \\
0.63\end{array}$ & $\begin{array}{l}2.79 \\
2.79 \\
2.81 \\
1.87 \\
0.75 \\
0.49 \\
0.26 \\
0.07 \\
0.05 \\
0.04 \\
0.03 \\
0.04 \\
0.11 \\
0.22\end{array}$ & $\begin{array}{l}2 \\
2 \\
2 \\
2 \\
2 \\
2 \\
2 \\
2 \\
2 \\
2 \\
2 \\
2 \\
2 \\
2\end{array}$ & $\begin{array}{r}-117 \pm 5 \\
-97 \pm 4 \\
-97 \pm 5 \\
-125 \pm 5 \\
-140 \pm 4 \\
-144 \pm 4 \\
-148 \pm 4 \\
-152 \pm 4 \\
-158 \pm 4 \\
-152 \pm 4 \\
-161 \pm 4 \\
-164 \pm 5 \\
-155 \pm 4 \\
-164 \pm 4\end{array}$ & $\begin{array}{l}-125 \\
-123 \\
-124 \\
-141 \\
-155 \\
-159 \\
-155 \\
-152 \\
-158 \\
-152 \\
-161 \\
-164 \\
-158 \\
-170\end{array}$ & $\begin{array}{r}8 \\
26 \\
27 \\
16 \\
16 \\
15 \\
7 \\
0 \\
0 \\
0 \\
0 \\
0 \\
4 \\
6\end{array}$ \\
\hline $\begin{array}{c}\text { Station } 18 \\
11.3 \\
20.9 \\
40.7 \\
80 \\
126.5 \\
175.2 \\
252.1 \\
599.1 \\
799.7 \\
998.9 \\
1197.6 \\
2244.5 \\
2995.5 \\
4495.7\end{array}$ & $\begin{array}{l}61^{\circ} \mathrm{S}, 30^{\circ} \mathrm{E} \\
1.7759 \\
1.6254 \\
-0.0172 \\
-1.62 \\
-1.213 \\
0.7429 \\
1.4748 \\
1.2922 \\
1.0488 \\
0.8452 \\
0.6426 \\
0.0032 \\
-0.2888 \\
-0.6071\end{array}$ & $\begin{array}{l}\text { E3.686 } \\
33.721 \\
33.891 \\
34.122 \\
34.198 \\
34.482 \\
34.635 \\
34.718 \\
34.714 \\
34.709 \\
34.7 \\
34.673 \\
34.664 \\
34.655\end{array}$ & $\begin{array}{l}26.938 \\
26.973 \\
27.211 \\
27.463 \\
27.509 \\
27.646 \\
27.72 \\
27.799 \\
27.812 \\
27.823 \\
27.828 \\
27.843 \\
27.849 \\
27.857\end{array}$ & $\begin{array}{l}44.3 \\
44.72 \\
45.56 \\
50.6 \\
57.35 \\
82.22 \\
90.64 \\
100.3 \\
107.1 \\
112.1 \\
116.4 \\
127.3 \\
127.3 \\
129\end{array}$ & $\begin{array}{l}2136 \\
2140 \\
2152 \\
2176 \\
2196 \\
2243 \\
2250 \\
= \\
- \\
= \\
= \\
\overline{2}\end{array}$ & $\begin{array}{l}6.32 \\
6.33 \\
6.41 \\
6.11 \\
5.56 \\
\overline{-} \\
0.85 \\
0.36 \\
0.31 \\
0.24 \\
0.21 \\
0.22 \\
0.24 \\
0.26\end{array}$ & $\begin{array}{l}2.83 \\
2.85 \\
2.85 \\
2.74 \\
2.44 \\
-\overline{-} \\
0.33 \\
0.15 \\
0.11 \\
0.1 \\
0.09 \\
0.07 \\
0.1 \\
0.09\end{array}$ & $\begin{array}{l}2 \\
2 \\
2 \\
2 \\
2 \\
2 \\
2 \\
2 \\
2 \\
2 \\
2 \\
2 \\
2 \\
2\end{array}$ & $\begin{array}{r}-74 \pm 5 \\
-85 \pm 5 \\
-80 \pm 5 \\
-87 \pm 5 \\
-91 \pm 5 \\
-124 \pm 5 \\
-146 \pm 5 \\
-143 \pm 6 \\
-166 \pm 5 \\
-164 \pm 5 \\
-162 \pm 5 \\
-156 \pm 5 \\
-157 \pm 5 \\
-154 \pm 5\end{array}$ & $\begin{array}{l}-114 \\
-114 \\
-116 \\
-121 \\
-127 \\
-152 \\
-155 \\
-146 \\
-169 \\
-164 \\
-162 \\
-156 \\
-157 \\
-154\end{array}$ & $\begin{array}{r}40 \\
30 \\
36 \\
34 \\
36 \\
28 \\
8 \\
4 \\
3 \\
0 \\
0 \\
0 \\
0 \\
0\end{array}$ \\
\hline $\begin{array}{c}\text { Station } 24 \\
10.4 \\
19.8 \\
40.7 \\
99 \\
150.5 \\
199.3 \\
320.7\end{array}$ & $\begin{array}{l}57^{\circ} \mathrm{S}, 30^{\circ} \mathrm{E} \\
2.2178 \\
2.2133 \\
2.2012 \\
-0.7262 \\
-1.6046 \\
-1.4569 \\
0.5166\end{array}$ & $\begin{array}{l}E \\
33.626 \\
33.625 \\
33.633 \\
33.92 \\
34.141 \\
34.234 \\
34.596\end{array}$ & $\begin{array}{l}26.853 \\
26.853 \\
26.862 \\
27.267 \\
27.476 \\
27.549 \\
27.751\end{array}$ & $\begin{array}{l}40.6 \\
40.6 \\
40.6 \\
50.32 \\
68.97 \\
73.03 \\
99.78\end{array}$ & $\begin{array}{c}2131 \\
2139 \\
2140 \\
- \\
2202 \\
2209 \\
2256\end{array}$ & $\begin{array}{l}6.27 \\
6.27 \\
6.26 \\
6.91 \\
6.62 \\
6.08 \\
1.6\end{array}$ & $\begin{array}{l}2.84 \\
2.82 \\
2.84 \\
3.06 \\
2.91 \\
2.68 \\
0.7\end{array}$ & $\begin{array}{l}2 \\
2 \\
2 \\
2 \\
2 \\
2 \\
2\end{array}$ & $\begin{array}{r}-83 \pm 5 \\
-77 \pm 5 \\
-74 \pm 5 \\
-81 \pm 5 \\
-87 \pm 5 \\
-92 \pm 5 \\
-141 \pm 5\end{array}$ & $\begin{array}{l}-111 \\
-111 \\
-111 \\
-120 \\
-139 \\
-143 \\
-157\end{array}$ & $\begin{array}{l}27 \\
33 \\
37 \\
39 \\
52 \\
51 \\
15\end{array}$ \\
\hline
\end{tabular}


Table 1 Data for the stations occupied during the CIVA1 cruise (Continued)

\begin{tabular}{|c|c|c|c|c|c|c|c|c|c|c|c|}
\hline $\begin{array}{l}\text { Depth } \\
\text { (m) }\end{array}$ & $\begin{array}{c}\text { Potential } \\
\text { temp. } \\
\left({ }^{\circ} \mathrm{C}\right)\end{array}$ & $\begin{array}{l}\text { Salinity } \\
\text { (S, psu) }\end{array}$ & Sig 0 & $\begin{array}{c}\mathrm{SiO}_{2} \\
\left(\mu \mathrm{mol} \mathrm{kg}{ }^{-1}\right) \\
\end{array}$ & $\begin{array}{c}\mathrm{SCO}_{2} \\
\left(\mathrm{mmol} \mathrm{kg}^{-1}\right)\end{array}$ & $\begin{array}{c}\mathrm{CFC}-11 \\
\left(\mathrm{pmol} \mathrm{kg} \mathrm{kg}^{-1}\right)\end{array}$ & $\begin{array}{c}\text { CFC-12 } \\
\left(\mathrm{pmol} \mathrm{kg}^{-1}\right)\end{array}$ & $\begin{array}{c}\text { Num. } \\
\text { of } \\
\text { meas. }\end{array}$ & $\begin{array}{l}\Delta^{14} \mathrm{C} \\
(\% \circ)\end{array}$ & $\begin{array}{l}\text { Nat. } \\
\Delta^{14} \mathrm{C} \\
(\% o)\end{array}$ & $\begin{array}{c}\text { Bomb } \\
\Delta^{14} \mathrm{C} \\
(\% 0)\end{array}$ \\
\hline $\begin{array}{r}496.9 \\
696.1 \\
997.1 \\
1195.8 \\
1992.9 \\
2995.3 \\
4495.2 \\
5422.2\end{array}$ & $\begin{array}{r}0.9574 \\
0.7337 \\
0.5577 \\
0.4318 \\
0.0367 \\
-0.3072 \\
-0.6165 \\
-0.7349\end{array}$ & $\begin{array}{l}34.695 \\
34.695 \\
34.695 \\
34.69 \\
34.675 \\
34.663 \\
34.654 \\
34.65\end{array}$ & $\begin{array}{l}27.803 \\
27.818 \\
27.829 \\
27.833 \\
27.842 \\
27.85 \\
27.856 \\
27.858\end{array}$ & $\begin{array}{l}108.3 \\
114.4 \\
120.9 \\
125.3 \\
129 \\
130.6 \\
129.4 \\
129\end{array}$ & $\begin{array}{c}2263 \\
2267 \\
2268 \\
2268 \\
- \\
\overline{-} \\
2258 \\
2256\end{array}$ & $\begin{array}{l}0.45 \\
0.38 \\
-\overline{0} \\
0.19 \\
0.22 \\
0.23 \\
0.28\end{array}$ & $\begin{array}{l}0.18 \\
0.15 \\
-\overline{11} \\
0.07 \\
0.08 \\
0.09 \\
0.11\end{array}$ & $\begin{array}{l}2 \\
2 \\
2 \\
2 \\
2 \\
2 \\
2 \\
2\end{array}$ & $\begin{array}{l}-153 \pm 5 \\
-151 \pm 5 \\
-151 \pm 5 \\
-175 \pm 5 \\
-177 \pm 5 \\
-171 \pm 4 \\
-156 \pm 4 \\
-150 \pm 4\end{array}$ & $\begin{array}{l}-157 \\
-155 \\
-153 \\
-177 \\
-177 \\
-171 \\
-156 \\
-153\end{array}$ & $\begin{array}{l}5 \\
4 \\
3 \\
3 \\
0 \\
0 \\
0 \\
3\end{array}$ \\
\hline $\begin{array}{c}\text { Station } 28 \\
10.9 \\
19.9 \\
39.5 \\
101.2 \\
151.1 \\
197.2 \\
323.1 \\
496.7 \\
701.6 \\
995.2 \\
1399.7 \\
2494.4 \\
3993.7 \\
4996.3 \\
5455.9\end{array}$ & $\begin{array}{l}54.3^{\circ} S, 30 \\
2.8814 \\
2.8829 \\
2.7778 \\
0.0656 \\
0.6092 \\
1.3819 \\
1.9407 \\
1.8816 \\
1.6213 \\
1.5408 \\
1.0201 \\
0.1553 \\
-0.4818 \\
-0.621 \\
-0.6523\end{array}$ & $\begin{array}{c}{ }^{\circ} E \\
33.876 \\
33.877 \\
33.952 \\
34.096 \\
34.294 \\
34.366 \\
34.572 \\
34.658 \\
34.689 \\
34.737 \\
-\overline{6} \\
34.68 \\
34.658 \\
34.657 \\
34.653\end{array}$ & $\begin{array}{l}26.998 \\
26.998 \\
27.066 \\
27.378 \\
27.456 \\
27.511 \\
27.632 \\
27.707 \\
27.752 \\
27.795 \\
27.823 \\
27.841 \\
27.853 \\
27.858 \\
27.858\end{array}$ & $\begin{array}{l}26.37 \\
26.37 \\
29.66 \\
48.6 \\
55.18 \\
65.07 \\
78.23 \\
85.23 \\
91.4 \\
91.81 \\
105.4 \\
126.4 \\
130.1 \\
129.7 \\
128.4\end{array}$ & $\begin{array}{l}2147 \\
2147 \\
2155 \\
2190 \\
2210 \\
2239 \\
2262 \\
2262 \\
2263 \\
2257 \\
2261 \\
2261 \\
2262 \\
2260\end{array}$ & $\begin{array}{l}5.91 \\
5.1 \\
5.94 \\
5.85 \\
4.81 \\
2.54 \\
0.81 \\
0.47 \\
0.49 \\
0.25 \\
0.22 \\
0.25 \\
0.21 \\
0.21 \\
0.19\end{array}$ & $\begin{array}{l}2.72 \\
2.53 \\
2.72 \\
2.67 \\
2.09 \\
1.08 \\
0.33 \\
0.17 \\
0.21 \\
0.08 \\
0.09 \\
0.07 \\
0.08 \\
0.09 \\
0.08\end{array}$ & $\begin{array}{l}2 \\
2 \\
2 \\
2 \\
2 \\
2 \\
2 \\
2 \\
2 \\
2 \\
2 \\
2 \\
2 \\
2 \\
2\end{array}$ & $\begin{array}{r}-69 \pm 6 \\
-81 \pm 5 \\
-83 \pm 5 \\
-97 \pm 5 \\
-80 \pm 5 \\
-109 \pm 5 \\
-142 \pm 5 \\
-150 \pm 5 \\
-153 \pm 5 \\
-147 \pm 4 \\
-156 \pm 4 \\
-164 \pm 5 \\
-164 \pm 4 \\
-156 \pm 4 \\
-151 \pm 4\end{array}$ & $\begin{array}{l}-96 \\
-96 \\
-100 \\
-119 \\
-125 \\
-135 \\
-148 \\
-155 \\
-158 \\
-147 \\
-156 \\
-164 \\
-164 \\
-156 \\
-151\end{array}$ & $\begin{array}{r}28 \\
16 \\
17 \\
21 \\
45 \\
26 \\
7 \\
5 \\
5 \\
0 \\
0 \\
0 \\
0 \\
0 \\
0\end{array}$ \\
\hline $\begin{array}{c}\text { Station } 38 \\
9.3 \\
18.8 \\
38.2 \\
79 \\
125.9 \\
172.9 \\
325.4 \\
576.9 \\
795.4 \\
998 \\
1198 \\
2498.4 \\
3994.5 \\
5183.5\end{array}$ & $\begin{array}{c}49.7^{\circ} S, 30 \\
4.5363 \\
4.5366 \\
4.5302 \\
3.139 \\
2.6988 \\
3.169 \\
2.6227 \\
2.3437 \\
2.4431 \\
2.3759 \\
2.3707 \\
1.1142 \\
-0.1069 \\
-0.4829\end{array}$ & $\begin{array}{l}{ }^{\circ} E \\
33.874 \\
33.874 \\
33.876 \\
33.982 \\
34.011 \\
34.125 \\
34.199 \\
34.36 \\
34.525 \\
34.613 \\
34.685 \\
34.735 \\
34.672 \\
34.656\end{array}$ & $\begin{array}{l}26.835 \\
26.836 \\
26.836 \\
27.061 \\
27.123 \\
27.173 \\
27.28 \\
27.433 \\
27.556 \\
27.632 \\
27.691 \\
27.825 \\
27.848 \\
27.853\end{array}$ & $\begin{array}{c}3.03 \\
3.89 \\
5.19 \\
15.12 \\
18.15 \\
20.31 \\
34.17 \\
56.5 \\
70.07 \\
75.32 \\
75.31 \\
105.6 \\
132.2 \\
135.2\end{array}$ & $\begin{array}{l}2121 \\
2120 \\
2119 \\
2150 \\
2154 \\
2162 \\
2188 \\
2233 \\
2254 \\
2258 \\
2255 \\
2272 \\
2257 \\
-\end{array}$ & $\begin{array}{l}5.29 \\
5.33 \\
5.3 \\
5.3 \\
5.12 \\
4.11 \\
2.96 \\
1.34 \\
0.51 \\
0.23 \\
0.16 \\
0.08 \\
0.25 \\
0.21\end{array}$ & $\begin{array}{l}2.95 \\
2.89 \\
2.88 \\
2.84 \\
2.74 \\
2.2 \\
1.56 \\
0.67 \\
0.26 \\
0.09 \\
0 \\
0 \\
0.12 \\
0.08\end{array}$ & $\begin{array}{l}2 \\
2 \\
2 \\
2 \\
2 \\
2 \\
2 \\
2 \\
2 \\
1 \\
2 \\
2 \\
2 \\
2\end{array}$ & $\begin{array}{r}-52 \pm 5 \\
-50 \pm 5 \\
-47 \pm 5 \\
-27 \pm 5 \\
-45 \pm 5 \\
-31 \pm 6 \\
-61 \pm 6 \\
-100 \pm 5 \\
-130 \pm 5 \\
-141 \pm 8 \\
-131 \pm 5 \\
-158 \pm 5 \\
-156 \pm 5 \\
-153 \pm 5\end{array}$ & $\begin{array}{r}-73 \\
-74 \\
-75 \\
-85 \\
-88 \\
-90 \\
-104 \\
-127 \\
-140 \\
-141 \\
-131 \\
-158 \\
-156 \\
-153\end{array}$ & $\begin{array}{r}22 \\
24 \\
29 \\
58 \\
43 \\
59 \\
43 \\
26 \\
10 \\
0 \\
0 \\
0 \\
0 \\
0\end{array}$ \\
\hline $\begin{array}{c}\text { Station } 52 \\
9.8 \\
19.4 \\
39.7 \\
100.5 \\
142.6 \\
197.4 \\
323.3 \\
499 \\
698.7 \\
1001.2 \\
1198.1 \\
2244.9 \\
3496.4 \\
4497.9 \\
\end{array}$ & $\begin{array}{l}44^{\circ} \mathrm{S}, 30^{\circ} \mathrm{E} \\
12.315 \\
12.297 \\
12.045 \\
9.2985 \\
8.7958 \\
7.916 \\
6.3703 \\
5.1576 \\
4.0819 \\
3.0136 \\
2.7672 \\
2.2081 \\
1.0783 \\
0.1862 \\
\end{array}$ & $\begin{array}{l}E \\
34.475 \\
34.472 \\
34.45 \\
34.596 \\
34.594 \\
34.497 \\
34.341 \\
34.3 \\
34.329 \\
34.421 \\
34.53 \\
34.793 \\
34.753 \\
34.69 \\
\end{array}$ & $\begin{array}{l}26.125 \\
26.128 \\
26.156 \\
26.756 \\
26.835 \\
26.892 \\
26.983 \\
27.128 \\
27.244 \\
27.423 \\
27.532 \\
27.789 \\
27.841 \\
27.846 \\
\end{array}$ & $\begin{array}{c}1.96 \\
1.96 \\
1.96 \\
7.34 \\
8.31 \\
9.78 \\
13.71 \\
23.19 \\
35.84 \\
58.5 \\
68.5 \\
72.65 \\
104.5 \\
132\end{array}$ & $\begin{array}{l}\overline{2061} \\
2058 \\
2116 \\
2123 \\
2135 \\
2143 \\
2180 \\
2196 \\
2239 \\
2251 \\
2236 \\
2267 \\
- \\
\end{array}$ & $\begin{array}{l}3.45 \\
3.41 \\
3.47 \\
3.62 \\
3.43 \\
3.36 \\
3.29 \\
2.2 \\
1.62 \\
0.73 \\
0.28 \\
0 \\
0.04 \\
0.13 \\
\end{array}$ & $\begin{array}{l}1.82 \\
1.87 \\
1.95 \\
1.89 \\
1.79 \\
1.75 \\
1.62 \\
1.09 \\
0.8 \\
0.32 \\
0.16 \\
0 \\
0 \\
0.1 \\
\end{array}$ & $\begin{array}{l}2 \\
2 \\
2 \\
2 \\
2 \\
2 \\
2 \\
2 \\
2 \\
2 \\
2 \\
2 \\
2 \\
2 \\
\end{array}$ & $\begin{array}{r}43 \pm 5 \\
49 \pm 5 \\
53 \pm 5 \\
55 \pm 5 \\
34 \pm 5 \\
33 \pm 5 \\
11 \pm 5 \\
-29 \pm 5 \\
-61 \pm 5 \\
-125 \pm 5 \\
-142 \pm 4 \\
-137 \pm 4 \\
-153 \pm 4 \\
-160 \pm 4 \\
\end{array}$ & $\begin{array}{l}-72 \\
-72 \\
-72 \\
-77 \\
-78 \\
-80 \\
-84 \\
-93 \\
-106 \\
-125 \\
-142 \\
-137 \\
-153 \\
-160 \\
\end{array}$ & $\begin{array}{r}115 \\
121 \\
125 \\
132 \\
112 \\
113 \\
94 \\
65 \\
45 \\
0 \\
0 \\
0 \\
0 \\
0\end{array}$ \\
\hline
\end{tabular}

Figure 2 shows a map including the WOCE/CIVA1 transect between $68^{\circ} \mathrm{S}$ and $44^{\circ} \mathrm{S}$ along $30^{\circ} \mathrm{E}$, where ${ }^{14} \mathrm{C}$ samples were collected. Also indicated are other stations in the same area where ${ }^{14} \mathrm{C}$ has been measured on previous campaigns: GEOSECS, WWSP, and INDIGO.

The $\theta$ and $\mathrm{S}$ along the CIVA1 transect (Fig. 3A,B) ${ }^{4}$ exhibit signatures of the major fronts that characterize the Southern Ocean: the Antarctic Divergence Zone (ADZ) between $63^{\circ} \mathrm{S}$ and $67^{\circ} \mathrm{S}$, the Weddell Gyre Front (WF) at $57^{\circ} \mathrm{S}$, the Polar Front (PF) at $52^{\circ} \mathrm{S}$, and the Subantarctic Front (SAF) at $48^{\circ} \mathrm{S}$ (Gordon 1971; Whitworth and Nowlin 1987; Orsi et al. 1993, 1995; Archambeau et al. 1998). The

${ }^{4}$ Note: Color versions of Figs. 3, 4, 7 and 9 are available at http://www.radiocarbon.org/Journal/v41n1/Leboucher/ 


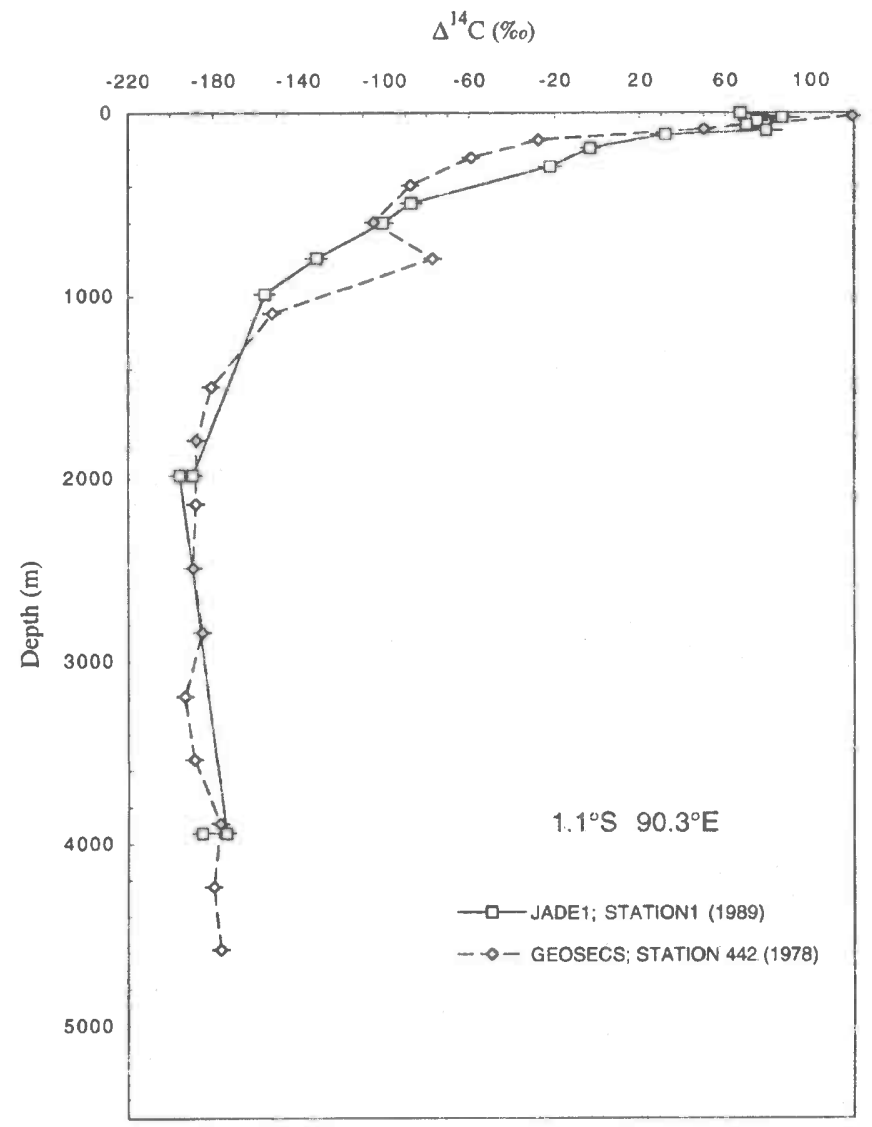

Figure 1 Profiles of measured $\Delta^{14} \mathrm{C}$ from GEOSECS station 442 and JADE1 station 1

principal water masses are likewise apparent. From the Antarctic continent to the PF, the Summer Surface Water (SSW) overlies the near freezing Winter Water (WW). Below the WW lies a massive amount of Circumpolar Deep Water $(\mathrm{CDW})$, which is relatively warm $\left(>0.1^{\circ} \mathrm{C}\right)$ and old (with respect to ventilation by contact with the surface). Beneath the $\mathrm{CDW}$ and along the bottom is found the Antarctic Bottom Water (AABW). In the AABW, one can trace the influence of the Weddell Sea Bottom Water (WSBW), which at its origin (the Weddell Sea) has a temperature $<-0.7^{\circ} \mathrm{C}$. Another water mass, the Subantarctic Surface Water (SASW), lies between the PF and the SAF. The SASW has higher temperatures and salinities than the more southern surface waters and is remarkable for its south-to-north downward tilt in $\theta$ and $\mathrm{S}$ isolines, where AAIW is formed. In this northern part of the CIVA1 section, intermediate level CDW bears a high salinity signature (maximum $34.8 \mathrm{psu}$ ) from its contact with North Atlantic Deep Water (NADW). AABW north of the Atlantic-Indian ridge is warmer and less dense than AABW to the south, which is closer to the source of the cold WSBW. Further description of CIVA1 hydrography can be found in Archambeau et al. (1998).

Table 1 provides the CIVA1 ${ }^{14} \mathrm{C}$ measurements. These data are presented as a composite latitude versus depth section (Fig. 4A) as well as individual profiles (Fig. 5A,B). The former reveals that the distribution of the measured ${ }^{14} \mathrm{C}$ roughly follows CIVA1 hydrography. A striking contrast is found across the PF: north of the PF, surface waters are enriched in ${ }^{14} \mathrm{C}$ (levels reach 55\%o); south of the $\mathrm{PF}$, the upper $200 \mathrm{~m}$ are depleted in ${ }^{14} \mathrm{C}$ (levels from $-70 \%$ to $-140 \%$ ). The Southern depletion is principally due to old CDW upwelling in the Antarctic Divergence Zone between $63^{\circ} \mathrm{S}$ and $67^{\circ} \mathrm{S}$ (Toggweiler and Wallace 1995). However, winter ice cover limits gas exchange and thus may play 


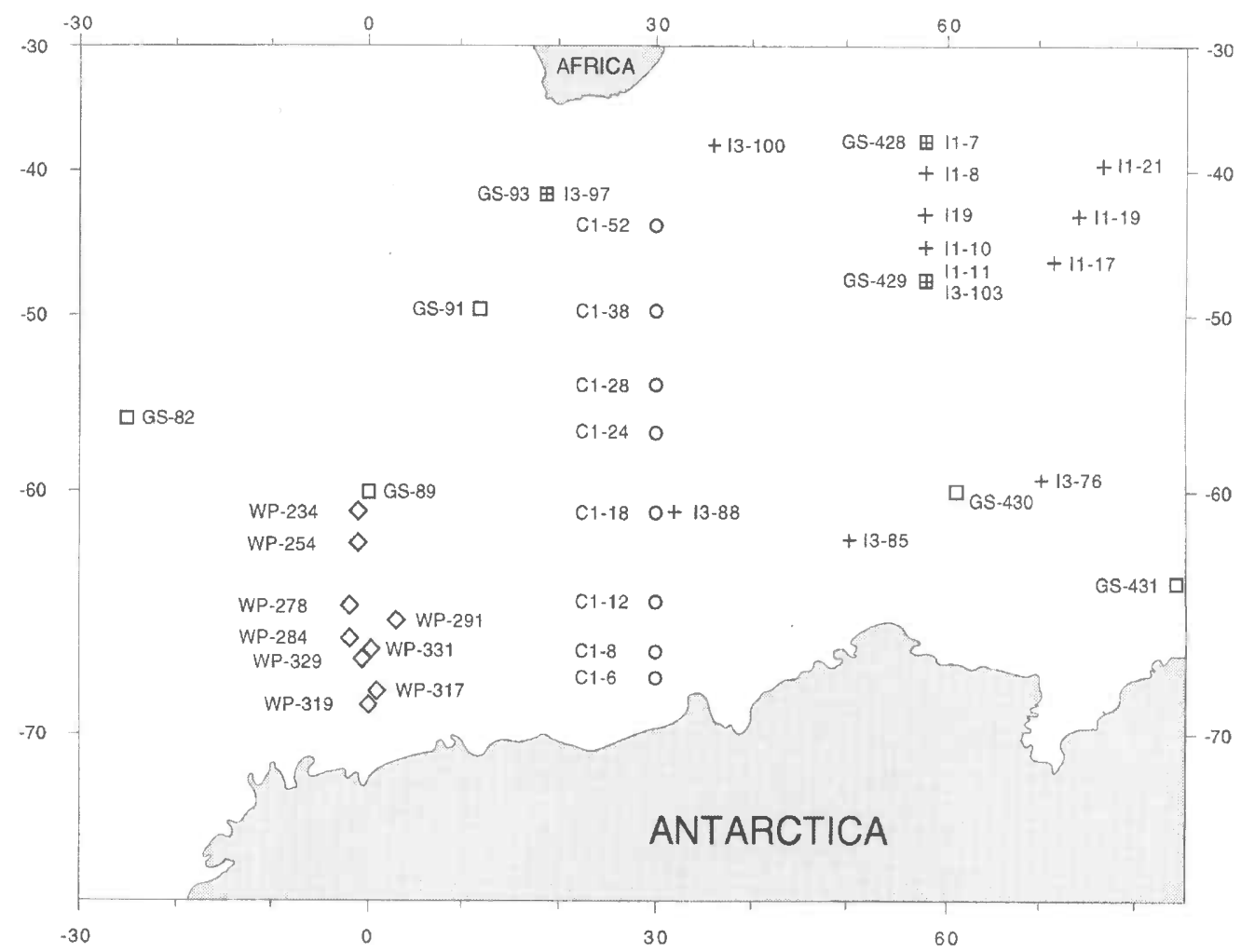

Figure 2 Stations occupied to collect samples for ${ }^{14} \mathrm{C}$ during CIVA1 (C1) as well as adjacent ${ }^{14} \mathrm{C}$ stations from GEOSECS (GS), WWSP (WP), INDIGO (I1 and I3)

some role (Weiss et al. 1979; Poisson and Chen 1987). North of the PF, ${ }^{14} \mathrm{C}$-enriched surface waters sink below warmer subantarctic water and move toward the north along downward sloping isopycnal surfaces, where AAIW is formed.

A core of old water $\left(\Delta^{14} \mathrm{C}\right.$ less than $-170 \%$ o ) is located near $57^{\circ} \mathrm{S}$ between 1000 and $2000 \mathrm{~m}$ (station 24). This corresponds to the oldest CDW. A shallow extension of old CDW is found near $66^{\circ} \mathrm{S}$ (station 8) with the oldest values (less than $-175 \%$ ) between $800 \mathrm{~m}$ and $1000 \mathrm{~m}$.

End members for and mixing between intermediate, deep, and bottom waters $\left(\sigma_{\theta}<27.7\right)$ are more easily seen on CIVA1's $\theta$-S diagram (Fig. 6A). The core of the CDW is identifiable by its salinity maximum induced by the contribution of NADW. Another influential water mass is the AABW, which forces most of the data points on the $\theta$-S plot to lie on a straight line between the CDW and $\mathrm{AABW}$ end-member. The ${ }^{14} \mathrm{C}$ data are helpful to pinpoint a third water mass component. Points from stations 8 and 24 reveal that the most ${ }^{14} \mathrm{C}$-depleted waters have slightly different $\theta$-S characteristics (Figs. 6B, 6C). These tendencies point to the older ${ }^{14} \mathrm{C}$-depleted Pacific Deep Water (PDW) as an important contributor. The same trend was found from measurements of ${ }^{3} \mathrm{He}$ in the Southern Ocean (Jean-Baptiste et al. 1991). The contribution of PDW to the CDW is also consistent with the return Pacific flow scheme described by Toggweiler and Samuels (1993) based on Pacific-Antarctic $\Delta^{14} \mathrm{C}$ difference, on the silica distribution in sediments of the Pacific sector of the Southern Ocean (Worthington 1977), and on previous inverse model results (Wunsch et al. 1983). The WOCE sec- 
tion $\mathrm{P} 6$ along $32^{\circ} \mathrm{S}$ in the Pacific Ocean shows a substantially older ${ }^{14} \mathrm{C}$ signal for this return flow (Key et al. 1996).

Figure 4A further shows that AABW has higher levels of ${ }^{14} \mathrm{C}\left(\Delta^{14} \mathrm{C}=-150 \%\right.$ o to $-160 \%$ o $)$ than does $\mathrm{CDW}$. The reason is that AABW originates principally in the Weddell Sea via mixing of newly formed WSBW with intermediate depth waters (Foster and Carmack 1976; Carmack and Foster 1977; Weiss et al. 1979; Mensch et al. 1996). The recent ventilation of the WSBW is clearly indicated by steady-state and transient tracer measurements $\left({ }^{14} \mathrm{C},{ }^{3} \mathrm{H}, \mathrm{CFC}-11, \mathrm{CFC}-12,{ }^{39} \mathrm{Ar},{ }^{18} \mathrm{O}\right.$ and helium isotopes) in the Weddell Sea (Bayer and Schlosser 1991; Schlosser et al. 1991; Mensch et al. 1996; Wepperning et al. 1996). GEOSECS ${ }^{14} \mathrm{C}$ data provide further evidence of such formation and indicate an eastward spreading of recently ventilated bottom waters (enriched in ${ }^{14} \mathrm{C}$ ) from the Weddell Sea (Fig. 7).

\section{DISCUSSION}

\section{Observed Change in Oceanic ${ }^{14} \mathrm{C}$}

Few previously collected ${ }^{14} \mathrm{C}$ data are available for ${ }^{14} \mathrm{C}$ in the same region (Fig. 2). Those that are available include measurements from GEOSECS (1973-1978), ANTV in the Weddell Sea (1986) and INDIGO (1985-1987). Figure 8 provides details of the measured change of surface ocean ${ }^{14} \mathrm{C}$ with time. Unfortunately, south of $65^{\circ} \mathrm{S}$ as well as between $55^{\circ} \mathrm{S}$ and $50^{\circ} \mathrm{S}$, no adjacent GEOSECS era data exist. Between about $65^{\circ} \mathrm{S}$ and $55^{\circ} \mathrm{S}$, surface ocean ${ }^{14} \mathrm{C}$ decreased progressively from $1973-$

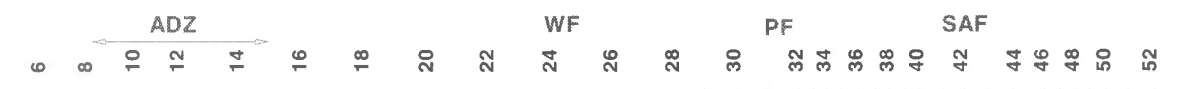

A
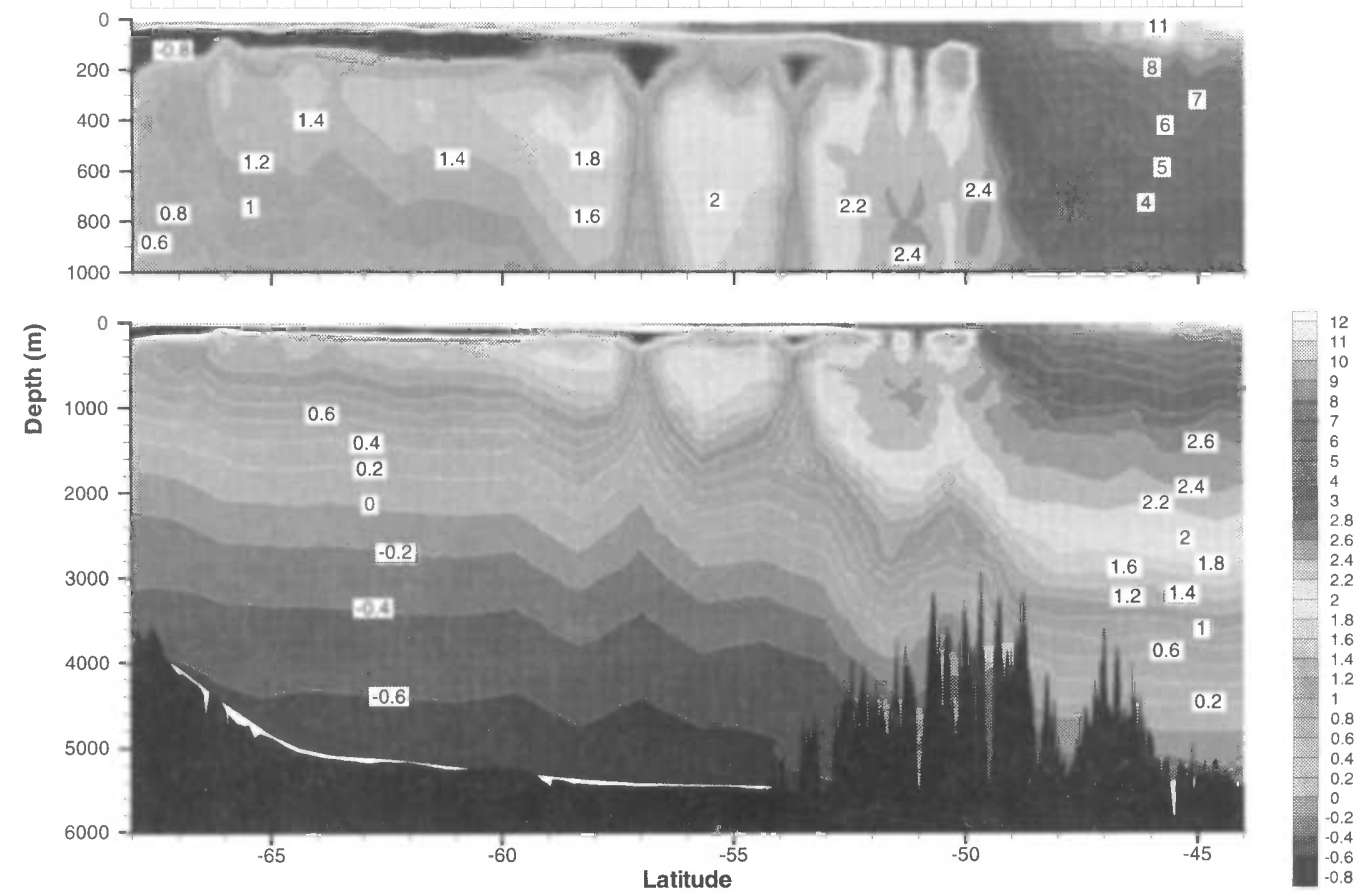

Figure 3 (A) Potential temperature $\theta$, (B) salinity S, and (C) CFC-12 concentrations along the CIVA1 section. Also indicated are frontal zones mentioned in the text (ADZ, WF, $\mathrm{PF}$ and $\mathrm{SAF})$. 


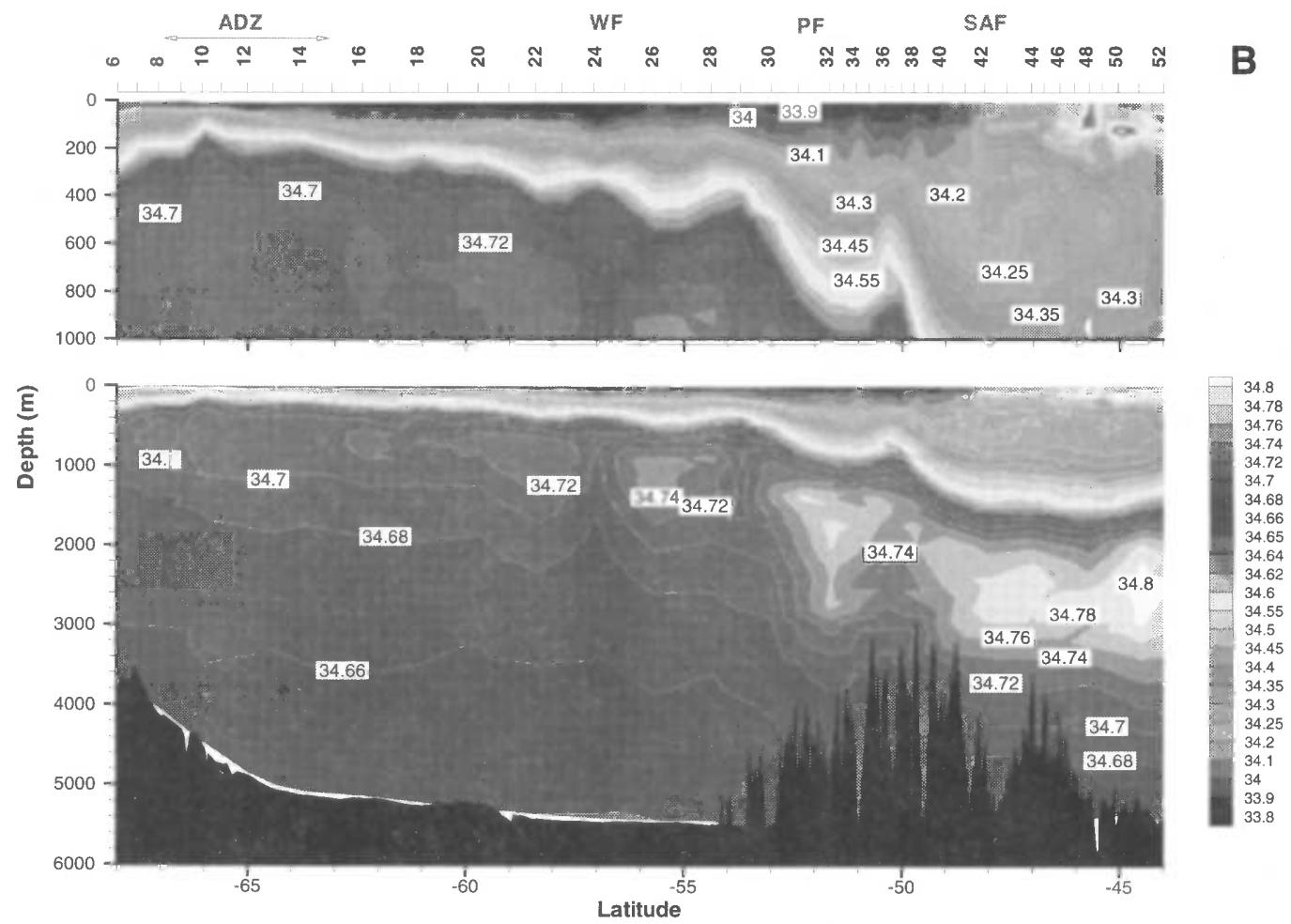

Figure 3B (See Fig. 3A)

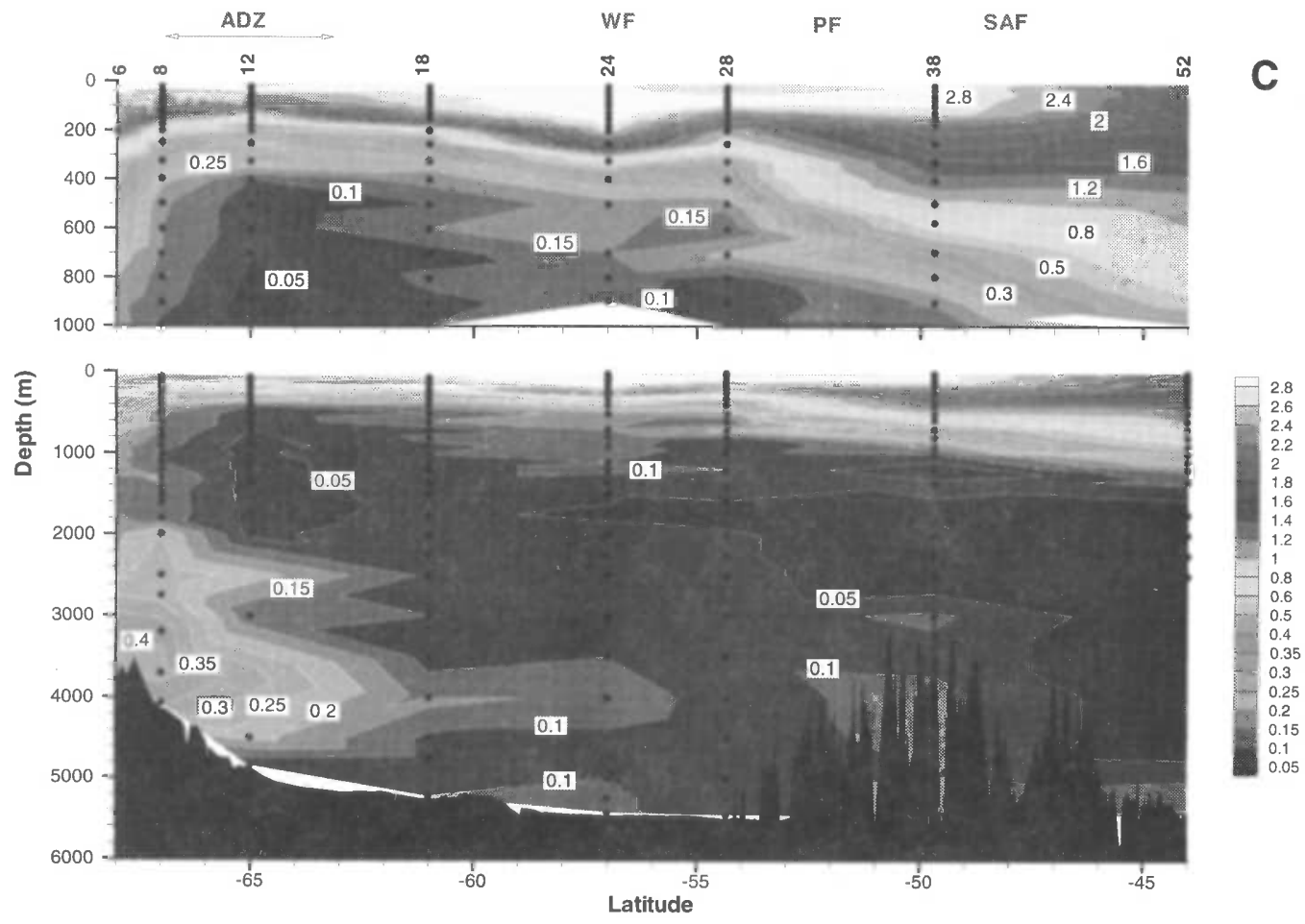

Figure 3C (See Fig. 3A) 
1978 to 1993 . This decreasing trend results from the decline in atmospheric ${ }^{14} \mathrm{C}$ and the replacement of the surface waters south of the Polar Front with upwelled CDW, which remains largely uncontaminated by bomb ${ }^{14} \mathrm{C}$ (Toggweiler and Wallace 1995). From $50^{\circ} \mathrm{S}$ to $44^{\circ} \mathrm{S}$, there also appears to be a reduction with time, assuming a linear spatial trend between those 2 CIVA data points.

Figure 9 provides a more in-depth look at the CIVA1 minus GEOSECS temporal change. The GEOSECS data in the Southern Ocean are sparse but were selected based on the proximity to the CIVA1 section. However, many of the chosen GEOSECS stations are far from the CIVA1 section, leading to substantial uncertainty about our calculated CIVA1-GEOSECS section. Nevertheless, natural variability must be substantially smaller than the large temporal changes in near-surface ${ }^{14} \mathrm{C}$ that have occurred since GEOSECS. Within the upper $200 \mathrm{~m},{ }^{14} \mathrm{C}$ has decreased substantially since GEOSECS. Just below, ${ }^{14} \mathrm{C}$ has increased. The increase extends deeper in the north than in the south. North of the CIVA1 Polar Front, the large subsurface increase in ${ }^{14} \mathrm{C}$ since GEOSECS (up to $+80 \%$ ) tags the formation of AAIW. The CDW remains largely uncontaminated by bomb ${ }^{14} \mathrm{C}$, a result that is consistent with the CIVA1 CFC data (Archambeau et al. 1998), which likewise reveal no significant recent contamination of the core of the CDW (Fig. 3C). Conversely, the AABW has been recently ventilated according to both the CIVA1-GEOSECS ${ }^{14} \mathrm{C}$ difference and the CIVA1 CFC data.

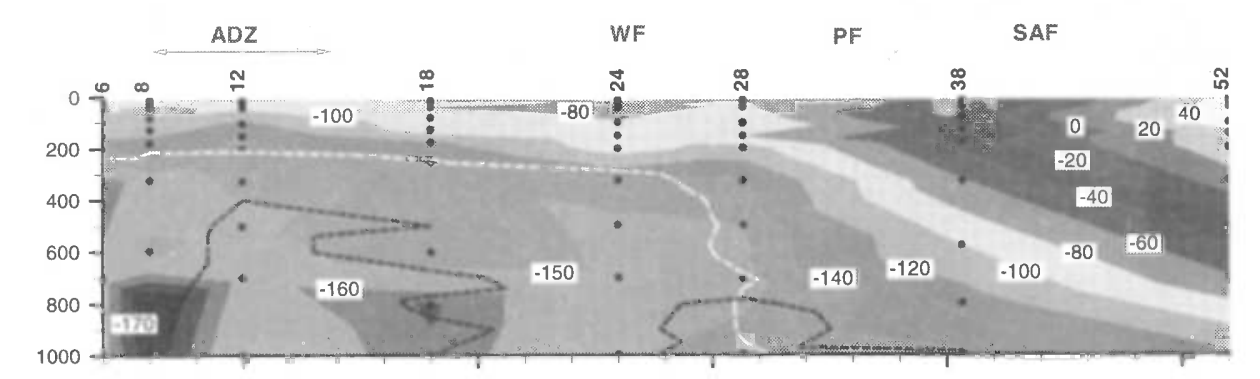

A

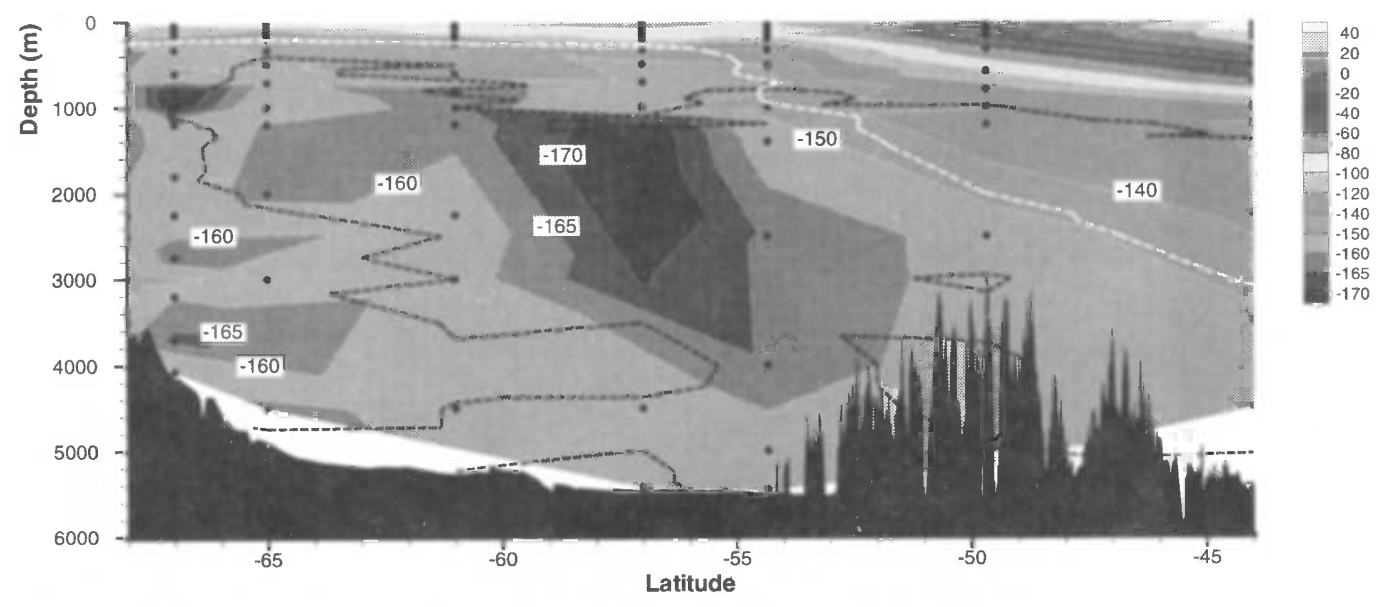

Figure 4 CIVA1 sections for (A) measured ${ }^{14} \mathrm{C}$ as well as (B) natural ${ }^{14} \mathrm{C}$ and $(\mathrm{C})$ bomb ${ }^{14} \mathrm{C}$ components estimated by our new

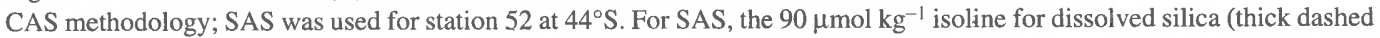
line) provides the limit for penetration of bomb ${ }^{14} \mathrm{C}$. For CAS, that limit is provided by the $0.1 \mathrm{pmol} \mathrm{kg}^{-1}$ isoline for CFC- 12 (thin dashed line). 


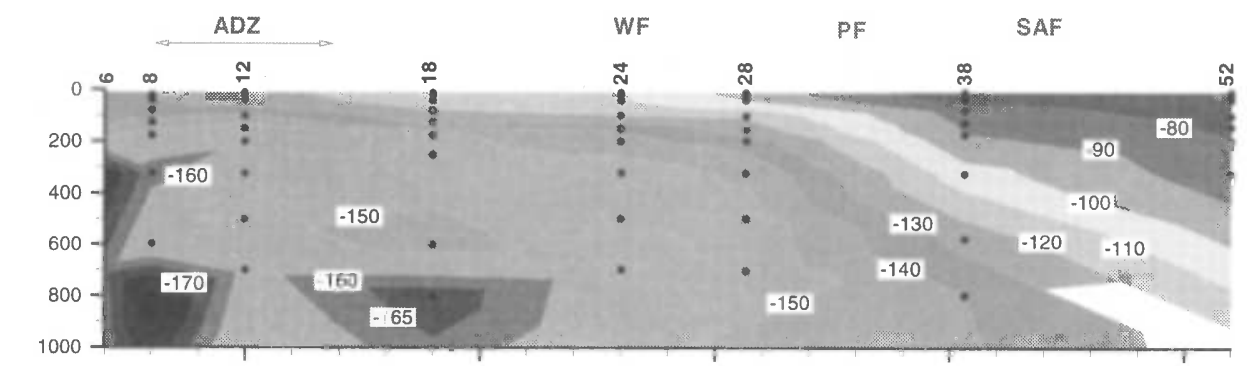

B

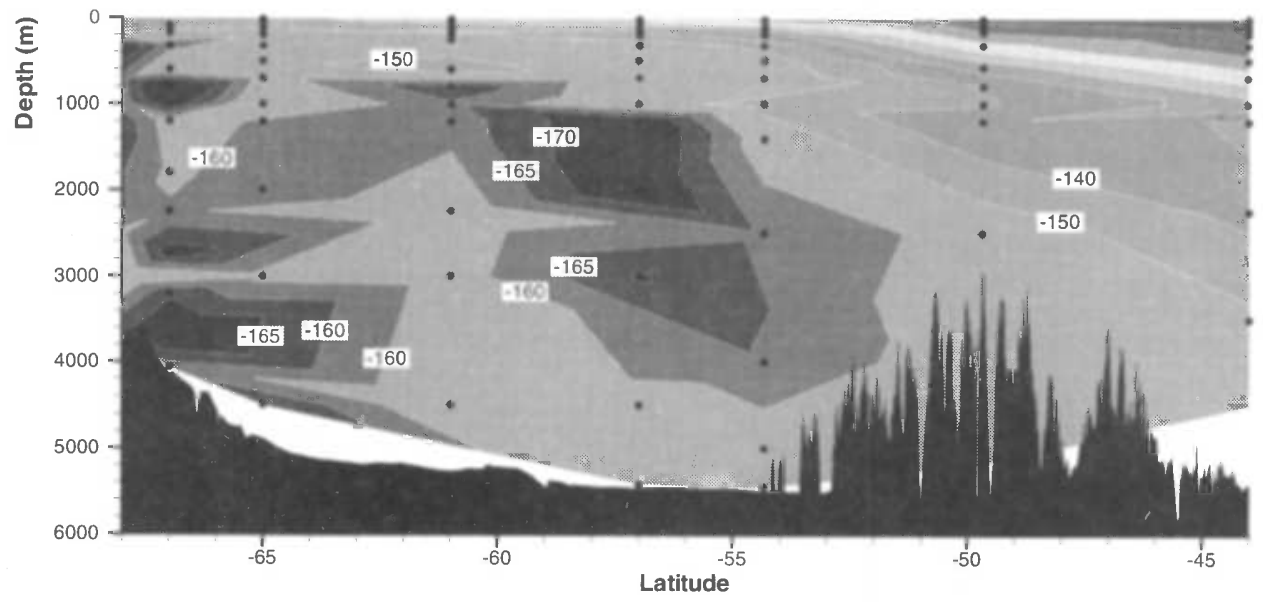

Figure 4B (See Fig. 4A)

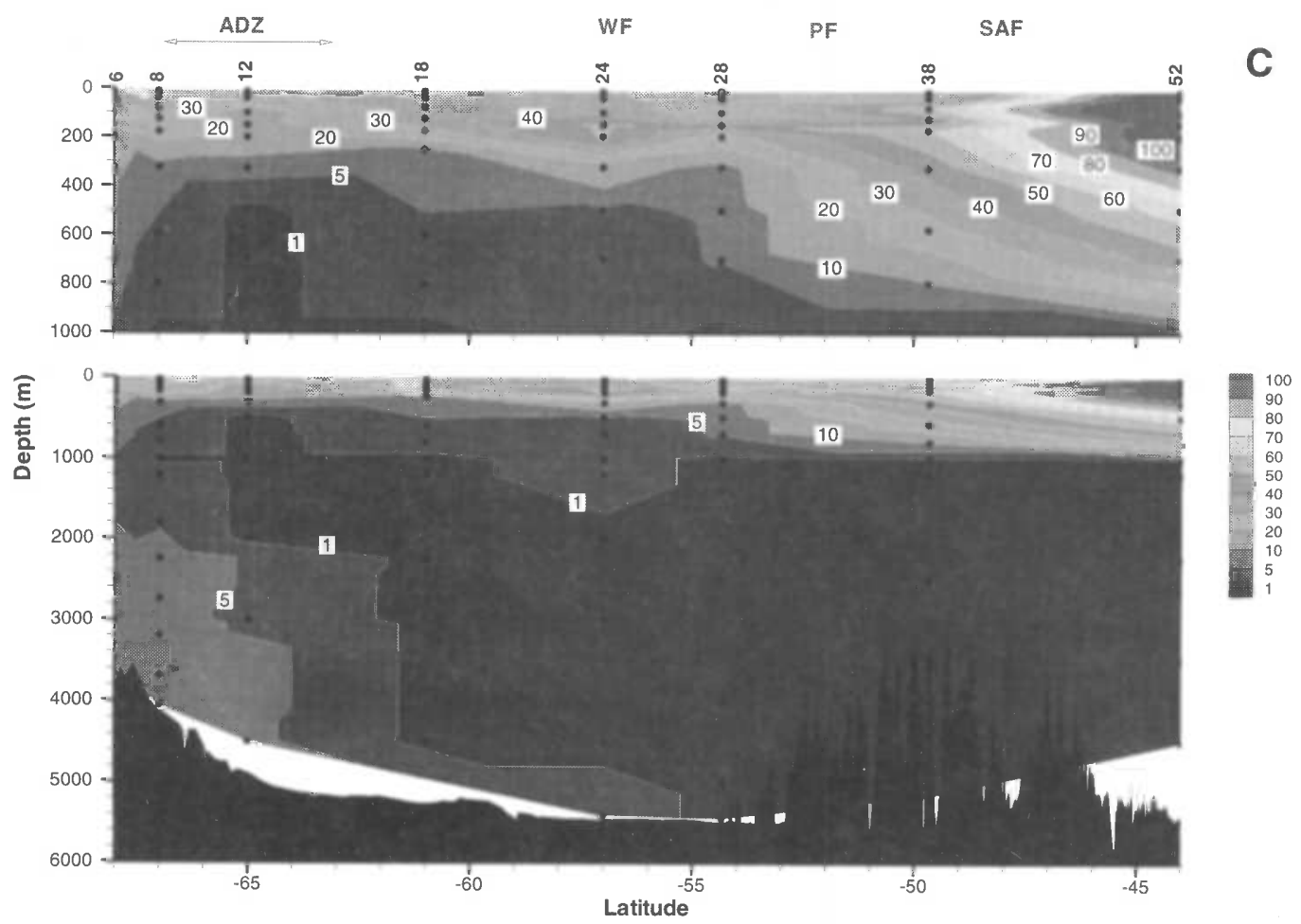

Figure 4C (See Fig. 4A) 
A
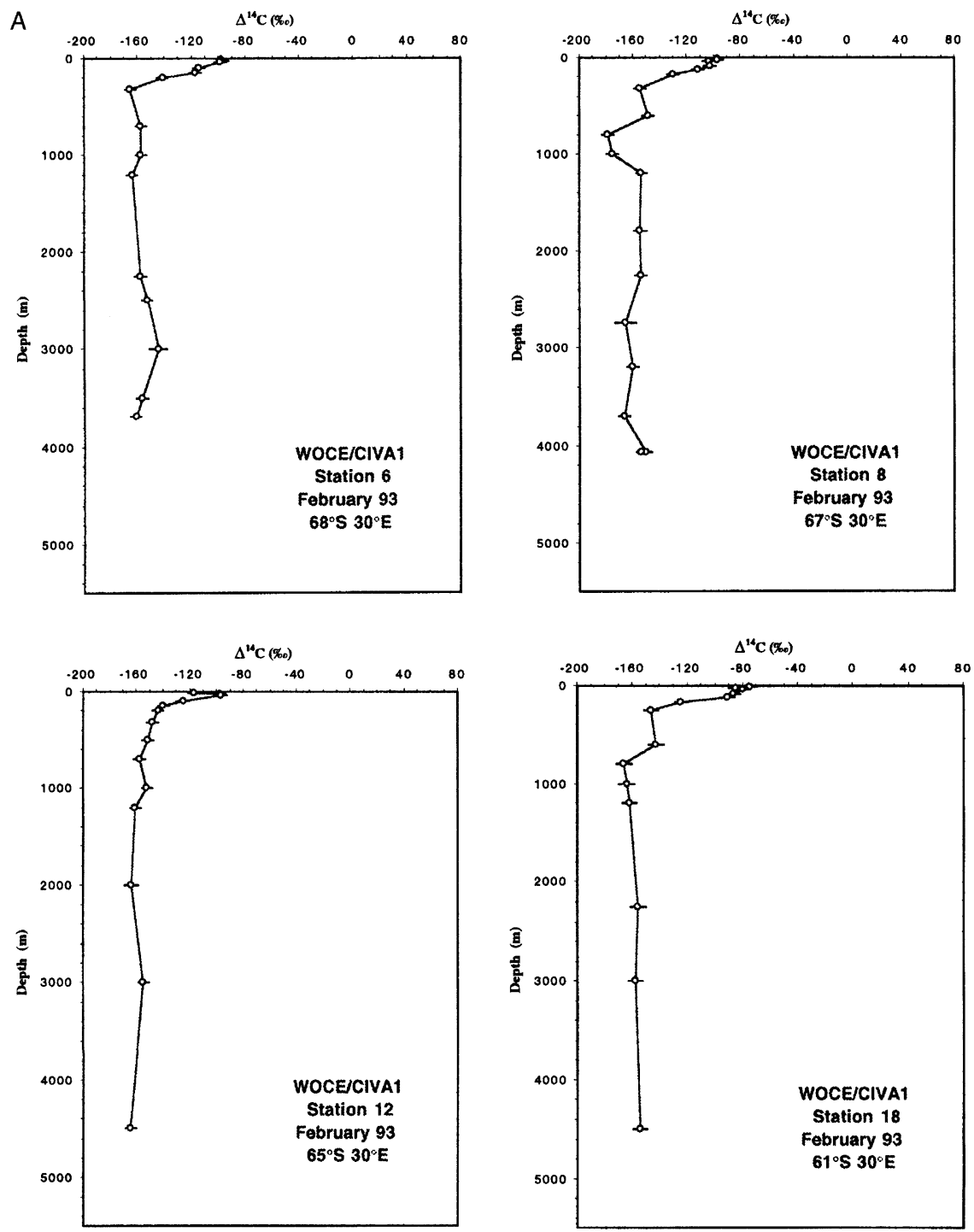

Figure 5A Profiles of measured $\Delta^{14} \mathrm{C}$ for CIVA1 stations $6,8,12$, and 18

\section{Estimating Natural and Bomb ${ }^{14} \mathrm{C}$}

Broecker et al. (1995) developed a general method to reconstruct the distribution of natural ${ }^{14} \mathrm{C}$ in the ocean. They applied their method to the GEOSECS (1972-1978), TTO (1980-1983) and SAVE (1987-1989) data to distinguish natural from bomb ${ }^{14} \mathrm{C}$. Besides surface prenuclear ${ }^{14} \mathrm{C}$ data, Broecker et al. (1995) used bomb tritium to delimit the penetration depth of bomb ${ }^{14} \mathrm{C}$, and the relationship between silica and natural ${ }^{14} \mathrm{C}$ to determine the latter in the upper water column. For CIVA1, we employ the same method for our one station that fell north of $45^{\circ} \mathrm{S}$ (station 52 at $44^{\circ} \mathrm{S}$ ). South of $45^{\circ} \mathrm{S}$, Broecker et al. (1995) rely purely on $\mathrm{SiO}_{2}$. In deep waters $\left(\mathrm{SiO}_{2}>90 \mu \mathrm{mol} \mathrm{kg}{ }^{-1}\right)$, Broecker et al. 
B
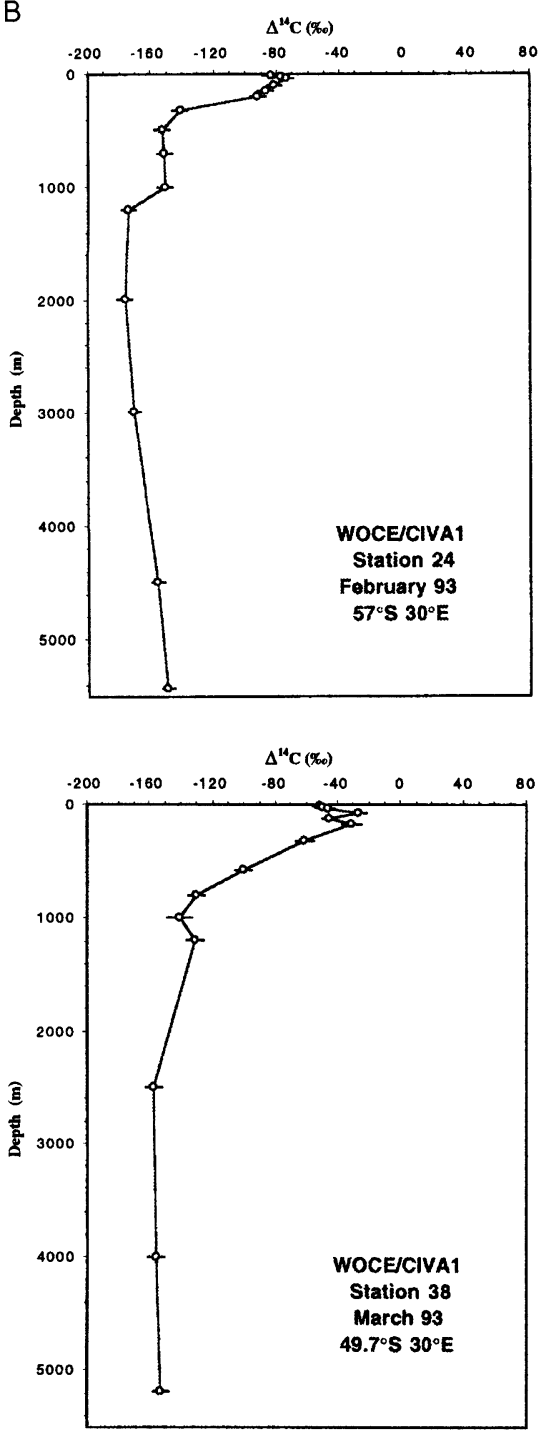
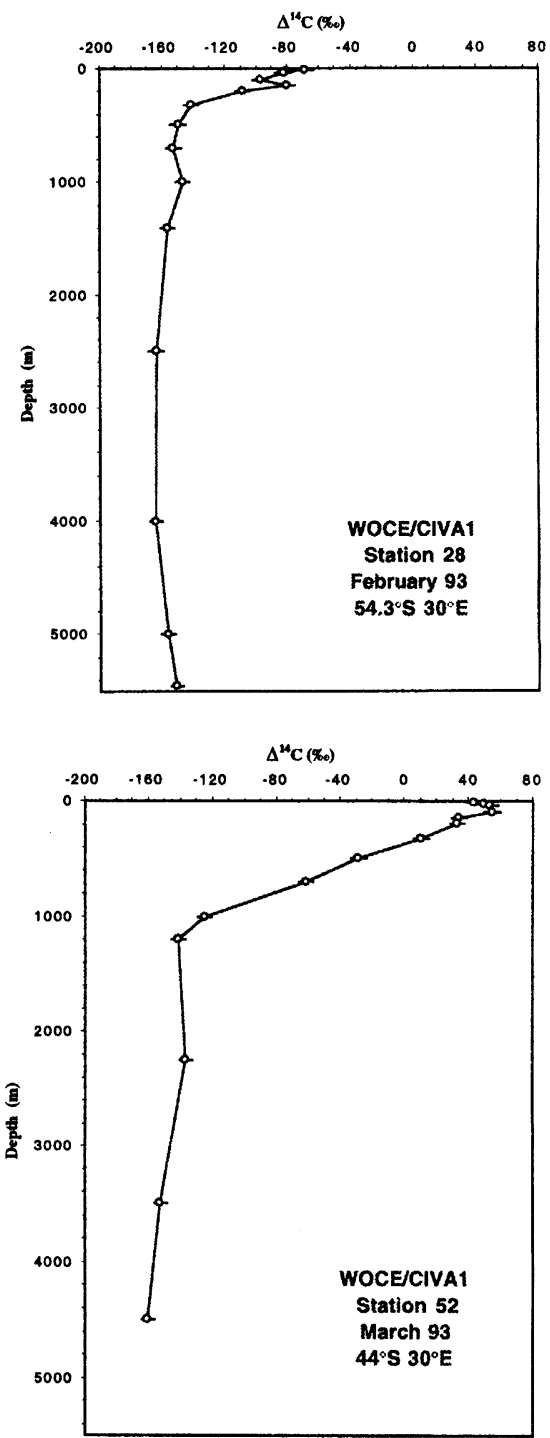

Figure 5B Profiles of measured $\Delta^{14} \mathrm{C}$ for CIVA1 stations $24,28,38$ and 52

(1995) consider that ${ }^{14} \mathrm{C}$ is entirely natural in origin (i.e., that deep waters were entirely free from bomb ${ }^{14} \mathrm{C}$ ). Although this is a reasonable approximation for the time of GEOSECS, only about $10 \mathrm{yr}$ after the peak in atmospheric ${ }^{14} \mathrm{C}$, such appears not to be the case for CIVA1 samples, collected about $20 \mathrm{yr}$ later.

At the time of CIVA1, it is possible that bomb ${ }^{14} \mathrm{C}$ had penetrated into deep waters of the Southern Ocean, where vertical mixing and advection are particularly active. To properly address such a possibility, we were forced to modify the method for the region south of $45^{\circ} \mathrm{S}$. For this, we employ a simple ventilation model (see Appendix) that relates deep water concentrations to historical surface values. The ventilation parameters of such a model are calibrated by CFC data, measured during CIVA1, 
because such gases have no natural component. Hence, this approach is termed the CFC Analogue Strategy (CAS). Then, with a data-based reconstructed history of surface ocean ${ }^{14} \mathrm{C}$ in the same region, we computed the penetration of bomb ${ }^{14} \mathrm{C}$.

\section{Silica Analogue Strategy and CFC Analogue Strategy}

The Silica Analogue Strategy (SAS) from Broecker et al. (1995) improves on previous methodology (Broecker et al. 1985) to separate natural and bomb ${ }^{14} \mathrm{C}$ in the ocean by exploiting the linear correlation between natural ${ }^{14} \mathrm{C}$ and dissolved silica found to exist in ${ }^{3} \mathrm{H}$-free waters throughout most of the oceans:

$$
\Delta^{14} \mathrm{C}_{\text {natural }}=-70-\mathrm{SiO}_{2}
$$
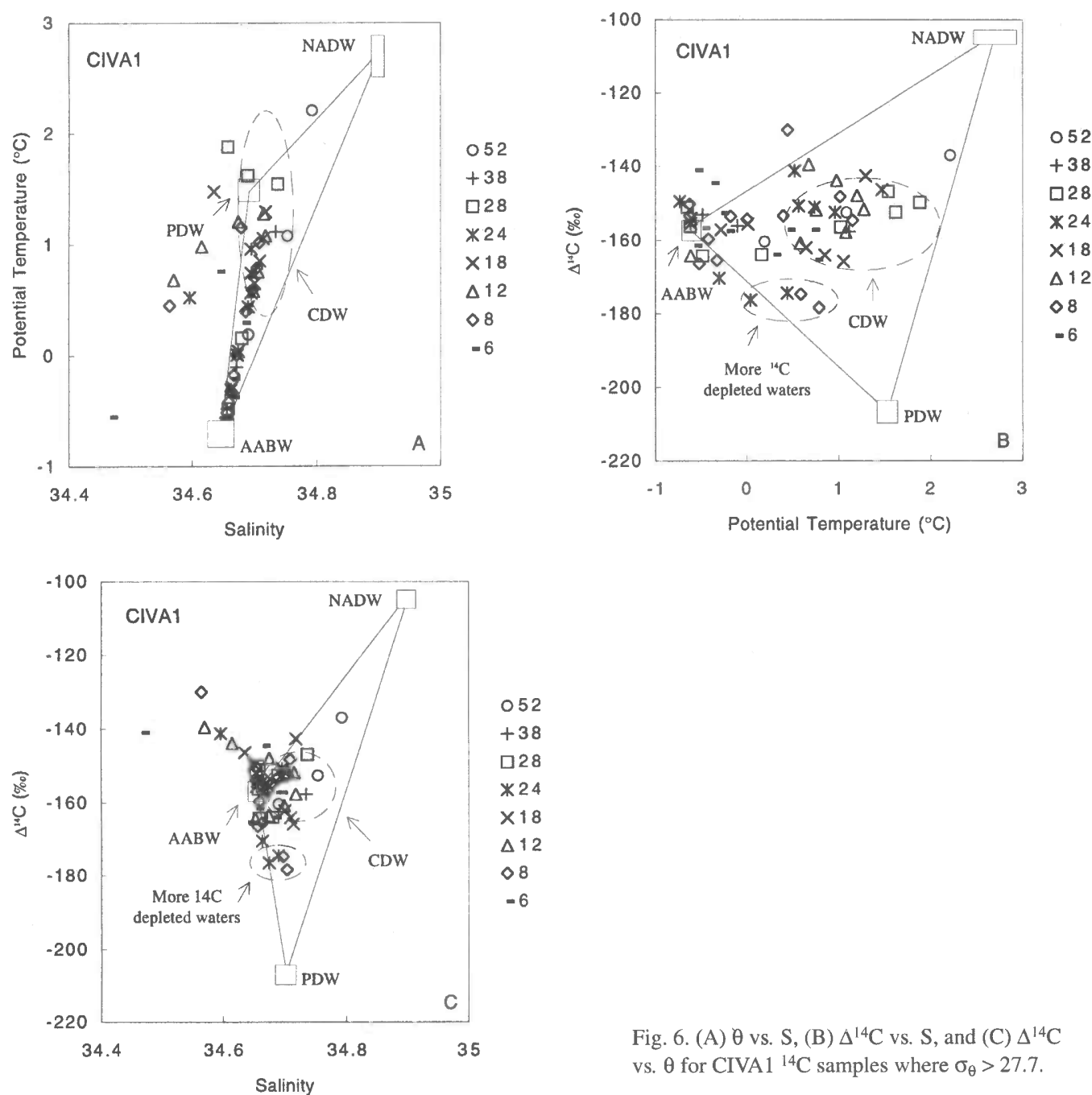

Fig. 6. (A) $\theta$ vs. $S$, (B) $\Delta^{14} \mathrm{C}$ vs. S, and (C) $\Delta^{14} \mathrm{C}$ vs. $\theta$ for CIVA $1{ }^{14} \mathrm{C}$ samples where $\sigma_{\theta}>27.7$. 


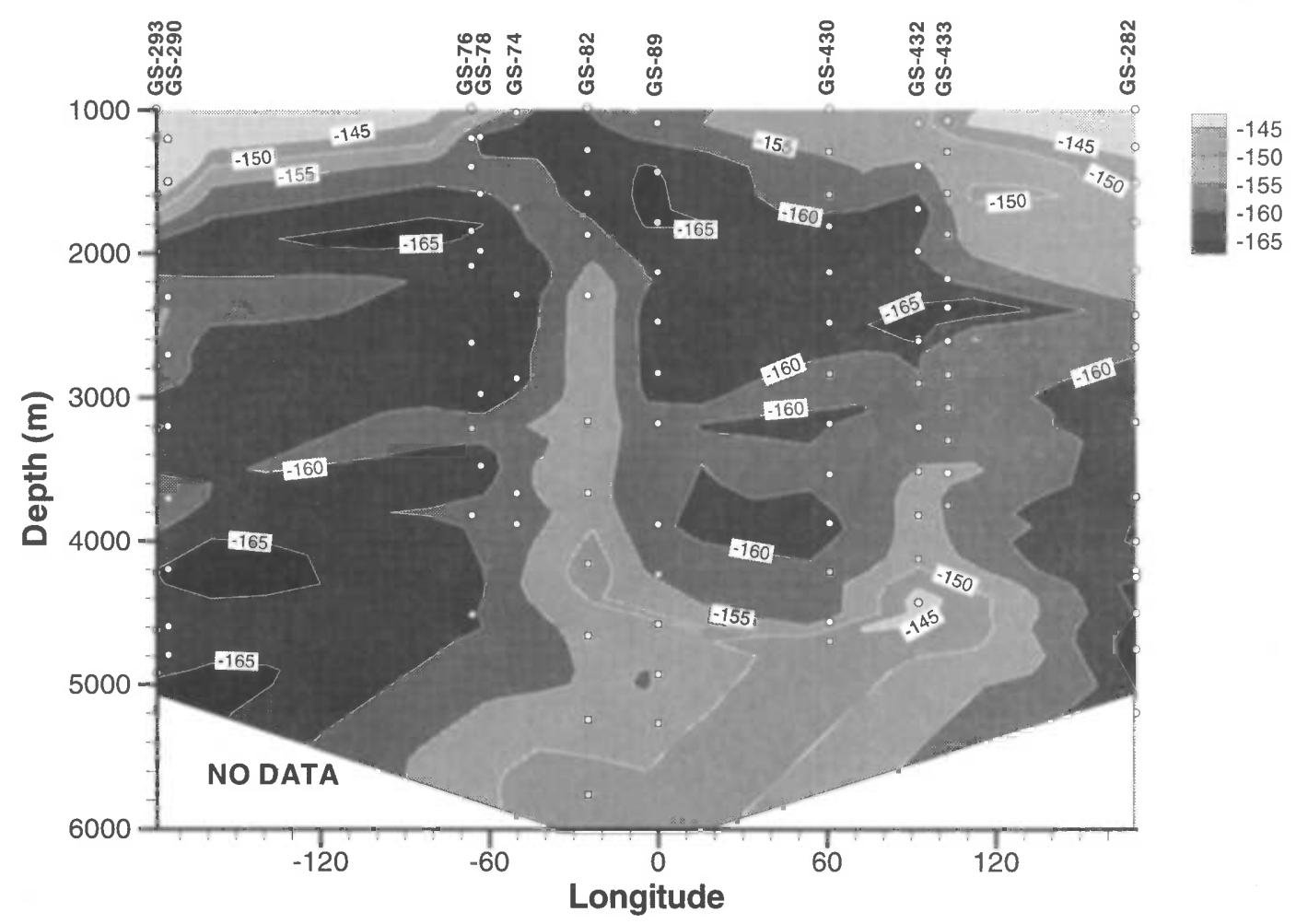

Figure 7 Longitudinal section of measured ${ }^{14} \mathrm{C}$ in the Antarctic Circumpolar Current (ACC) from GEOSECS (19721978). Latitudes of stations vary between $52^{\circ} \mathrm{S}$ and $62^{\circ} \mathrm{S}$.

where $\Delta^{14} \mathrm{C}$ is in $\% o$ and $\mathrm{SiO}_{2}$ is in $\mu \mathrm{mol} \mathrm{kg}{ }^{-1}$. Broecker et al. (1995) estimate the uncertainty of the natural ${ }^{14} \mathrm{C}$ thus calculated as $\pm 10 \%$. Figure 10 is a plot of ${ }^{14} \mathrm{C}$ versus silica for GEOSECS, INDIGO3, and CIVA1 data from the Southern Ocean south of $50^{\circ} \mathrm{S}$. Also given is the linear regression from equation (1). For waters south of $45^{\circ} \mathrm{S}$, Broecker et al. (1995) apply equation (1) when $\mathrm{SiO}_{2}<90 \mu \mathrm{mol} \mathrm{kg}{ }^{-1}$. They assume that waters with $\mathrm{SiO}_{2}>90 \mu \mathrm{mol} \mathrm{kg}^{-1}$ are uncontaminated with bomb ${ }^{14} \mathrm{C}$. However, south of $45^{\circ} \mathrm{S}$, contamination of deep waters by bomb ${ }^{14} \mathrm{C}$ is much more likely for CIVA1-era samples. Figure 10 suggests that bomb ${ }^{14} \mathrm{C}$ has invaded deep waters since GEOSECS: for waters with $\mathrm{SiO}_{2}$ between 90 and $100 \mu \mathrm{mol} \mathrm{kg}-1,{ }^{14} \mathrm{C}$ is greater during CIVA1 than during GEOSECS. Thus, for CIVA1, one cannot use the SAS method alone, which assumes that measured variability in deep water ${ }^{14} \mathrm{C}$ is due to natural variation. Instead, south of $45^{\circ} \mathrm{S}$, we modified the technique in defining 3 separate regions (Fig. 4A):

1. In the waters where $\mathrm{SiO}_{2}<90 \mu \mathrm{mol} \mathrm{kg}{ }^{-1}$, natural ${ }^{14} \mathrm{C}$ is deduced from Broecker et al.'s (1995) SAS methodology.

2. In the core of the CDW, where $\Delta^{14} \mathrm{C}$ values are the lowest and have not changed since the time of GEOSECS, we consider the ${ }^{14} \mathrm{C}$ to be entirely prenuclear in origin. Arbitrarily, we choose the weak CFC-12 concentrations of $0.1 \mathrm{pmol} \mathrm{kg}^{-1}$ as a limit to any anthropogenic contamination. We are unable to employ the CFC-11/CFC-12 dating method near the surface, nor in deep waters. Indeed, the ratio CFC-11/CFC-12 is not usable to date young near-surface waters in CIVA1 because since the mid-1970s, growth rates of atmospheric CFC-11 and CFC-12 have 


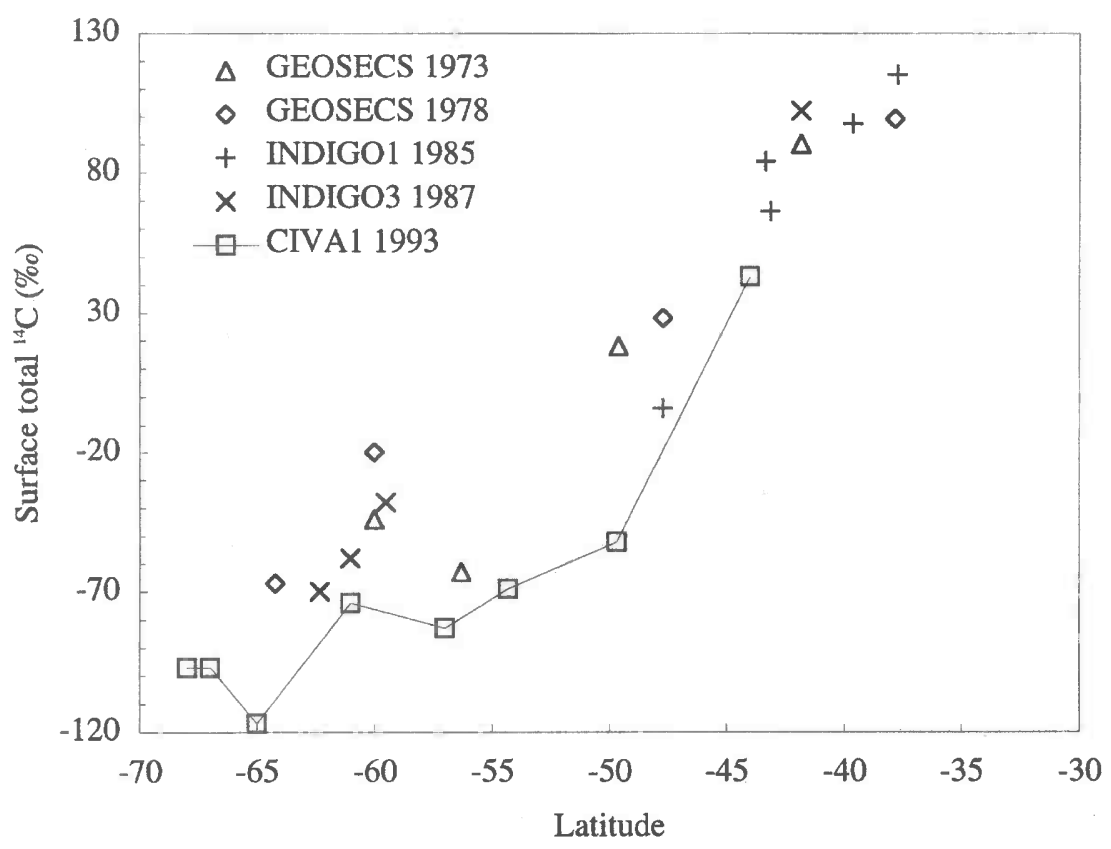

Figure 8 Measured surface ocean ${ }^{14} \mathrm{C}$ from GEOSECS, INDIGO and CIVA1 as a function of latitude for the region between $25^{\circ} \mathrm{W}$ to $85^{\circ} \mathrm{E}$ and $70^{\circ} \mathrm{S}$ to $30^{\circ} \mathrm{S}$.

been the same. Furthermore, in CIVA's deep waters where the CFC concentrations are very low, uncertainty in the CFC-11/CFC-12 ratio is too large to be of any use.

3. Elsewhere (i.e., mainly in the ventilated southernmost part of the section), our vertical mixing model and CFCs from CIVA1 are used to calculate the annual ventilation rate of any water parcel, and subsequently, the bomb ${ }^{14} \mathrm{C}$ contribution based on a reconstructed history of surface bomb ${ }^{14} \mathrm{C}$. By dealing directly with surface ocean concentrations, we avoid problems due to the roughly 100 -fold difference in the time required for ${ }^{14} \mathrm{C}$ versus $\mathrm{CFCs}$ to equilibrate between the atmosphere and surface ocean (Broecker and Peng 1974).

\section{Natural Versus Bomb ${ }^{14} \mathrm{C}$}

Figure 4B shows the computed natural ${ }^{14} \mathrm{C}$. Surface values of natural ${ }^{14} \mathrm{C}$ increase from south to north from $-132 \%$ to $-72 \%$. Our lowest surface values in the far south are consistent with the rare existing data set (Broecker et al. 1985; Bard 1988; Toggweiler and Samuels 1993; Berkman and Forman 1996), especially considering the uncertainties from analysis, the Suess effect (5\%o to $12 \%$ o [Berkman and Forman 1996]), the silica-natural ${ }^{14} \mathrm{C}$ relationship $( \pm 10 \%$ ), and natural spatial variability. Waters north of the PF, where AAIW forms, have higher natural ${ }^{14} \mathrm{C}$, largely because they rest longer at the surface and thus equilibrate more extensively with the atmosphere; also circulation patterns transport natural ${ }^{14} \mathrm{C}$ to the north as described previously. South of the PF, a large portion of the intermediate and deep waters have natural ${ }^{14} \mathrm{C}$ values lower than $-160 \%$, which is the average value of the waters of the Antarctic Circumpolar Current (Broecker et al. 1995).

The bomb ${ }^{14} \mathrm{C}$ results (Fig. 4C) are consistent with the observed trends of the total $\Delta^{14} \mathrm{C}$ values: waters are poor in bomb ${ }^{14} \mathrm{C}$ south of the $\mathrm{PF}$ and richer in the north; intermediate, deep, and bottom 


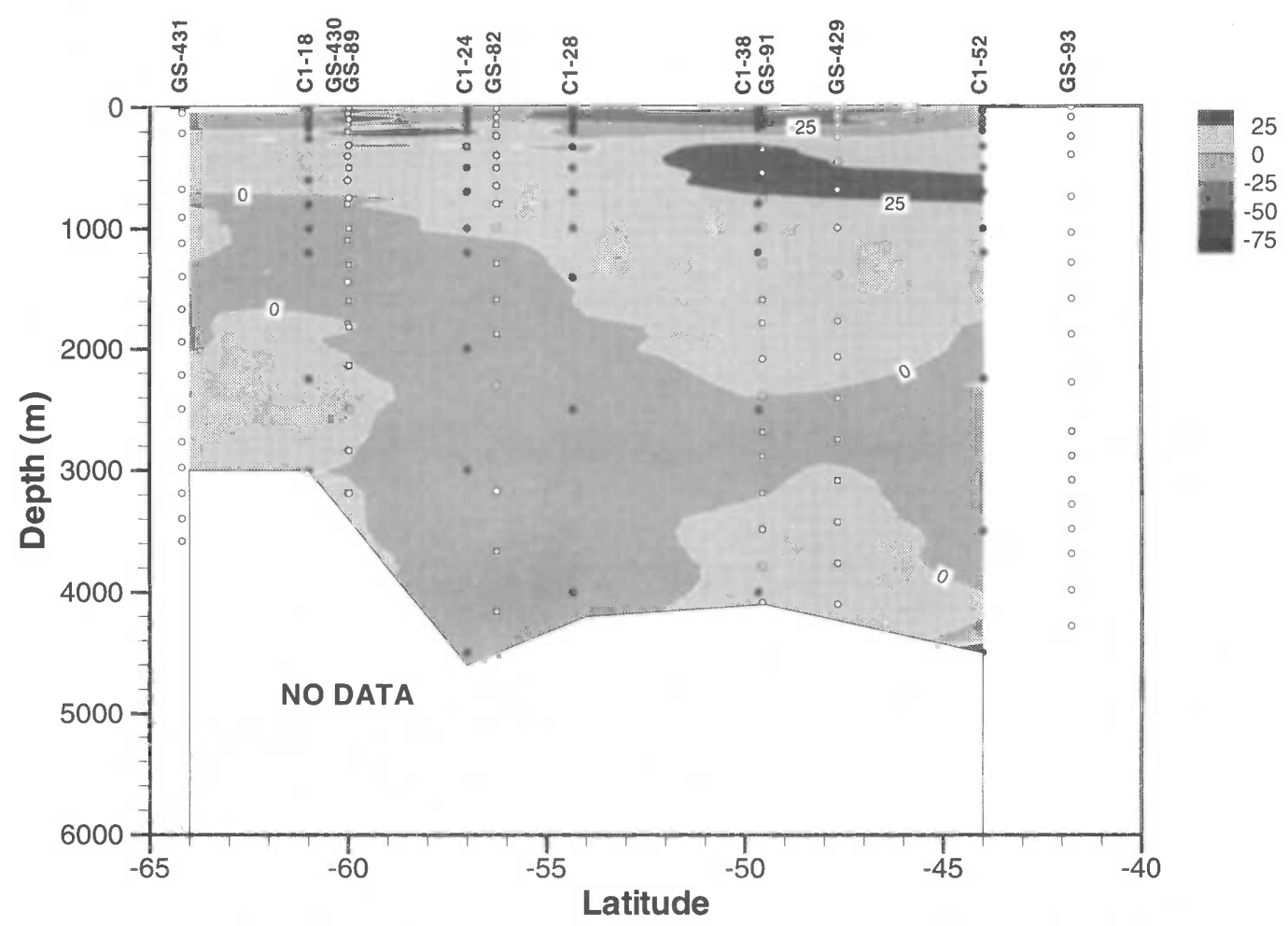

Figure 9 Section of the measured change in ${ }^{14} \mathrm{C}$ between GEOSECS and CIVA1. GEOSECS stations are taken from longitudes between $25^{\circ} \mathrm{W}$ and $85^{\circ} \mathrm{E}$. GEOSECS and CIVA1 station data were triangulated then interpolated to the same 1-degree latitudinal grid before taking differences.

waters contain little if any bomb ${ }^{14} \mathrm{C}$. The only exception is where substantial bomb ${ }^{14} \mathrm{C}$ is detected between 2000 and $5000 \mathrm{~m}$ in the far south along the continental slope. Deep and bottom waters in the northern portion of the section contain insignificant levels.

\section{Bomb ${ }^{14} \mathrm{C}$ Inventories}

Following Broecker et al. (1985), we calculated the vertical integral of bomb ${ }^{14} \mathrm{C}$ (also known as the inventory) as the area between bomb and natural ${ }^{14} \mathrm{C}$ profiles (Table 2, Fig. 11). With our method, inventories range from 1.7 to $10.9 \times 10^{9}$ atoms $\mathrm{cm}^{-2}$. Inventories are larger north of the $\mathrm{PF}$ (stations 38 and 52) as well as in the far south, at stations 6 and 8 . North of $45^{\circ} \mathrm{S}$ (station 52), the bomb ${ }^{14} \mathrm{C}$ inventory is highest $\left(10.9 \pm 1.6 \times 10^{9}\right.$ atoms $\left.\mathrm{cm}^{-2}\right)$ and its uncertainty is lowest: both the SAS and CAS methods give the same inventory. We were able to properly apply the SAS method at station 52, because our measured CIVA $1{ }^{3} \mathrm{H}$ (not shown) was well above background levels. Figure $11 \mathrm{com}-$ pares CIVA1 bomb ${ }^{14} \mathrm{C}$ inventories to those from GEOSECS and INDIGO. The temporal change is similar in structure to that seen for surface concentrations (Fig. 8). Around $60^{\circ} \mathrm{S}$, the differences between inventories during CIVA1 (CAS) and GEOSECS (SAS) tend towards zero: the ${ }^{14} \mathrm{C}$ loss near the surface is compensated by buildup at depth (Fig. 4C). Around $60^{\circ} \mathrm{S}$, when the SAS methodology is used, CIVA1 inventories are only $20 \%$ to $50 \%$ of those determined using CAS. Further south, stations at $67^{\circ} \mathrm{S}$ and $68^{\circ} \mathrm{S}$ exhibit the largest differences between the SAS and CAS methods.

Uncertainties concerning the Southern Ocean's bomb ${ }^{14} \mathrm{C}$ inventories are large but their magnitude is relatively small compared to the inventories throughout most of the rest of the ocean (Broecker et 


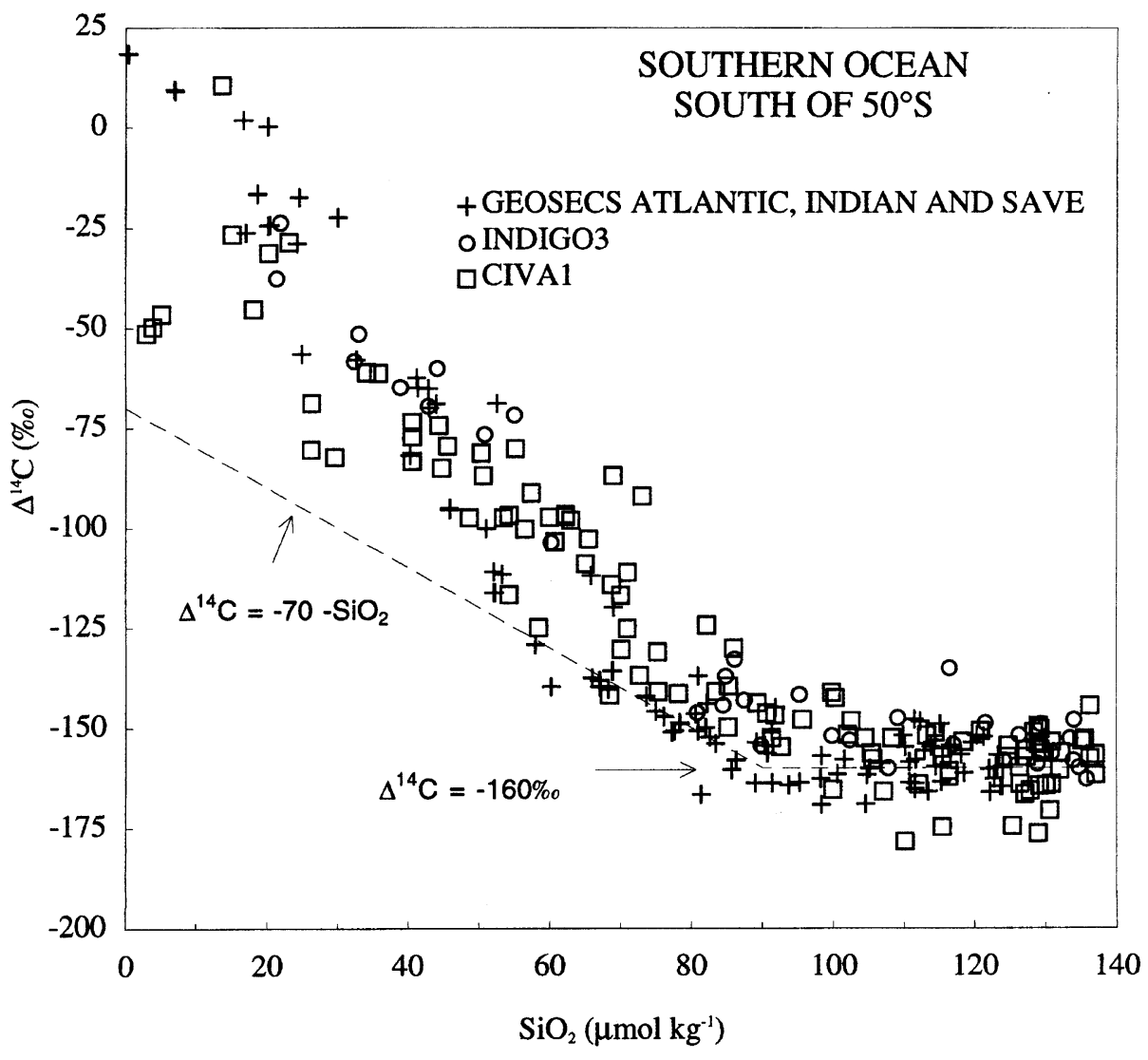

Figure $10{ }^{14} \mathrm{C}$ versus dissolved $\mathrm{SiO}_{2}$ for stations taken south of $50^{\circ} \mathrm{S}$ from the GEOSECS, INDIGO3, and CIVA1 expeditions. Also provided is the linear correlation between the natural $\Delta^{14} \mathrm{C}$ and silica for tritium-free waters (Broecker et al. 1995).

al. 1995). Thus, uncertainties in this region do not substantially alter estimates of the global ocean inventory of bomb ${ }^{14} \mathrm{C}$. Regional patterns of bomb ${ }^{14} \mathrm{C}$ inventories are generally useful to help evaluate the behavior of OGCMs (Toggweiler et al. 1989b). However, they are less useful in the Southern Ocean, due to the large uncertainties there. On the other hand, levels of bomb ${ }^{14} \mathrm{C}$ near the surface in this same region have much smaller uncertainties than do corresponding horizontal and vertical gradients, and are thus more useful for model validation.

\section{CONCLUSION}

To complement the sparse ${ }^{14} \mathrm{C}$ data set in the Southern Ocean, AMS ${ }^{14} \mathrm{C}$ measurements were made on recently collected samples taken along the CIVA1 cruise track. The measured ${ }^{14} \mathrm{C}$ distribution reveals a dramatic contrast between samples taken south and north of the PF. Surface waters in the south are depleted due to upwelling of old CDW at the ADZ, which drives transport to the north; northern surface waters are rich in ${ }^{14} \mathrm{C}$ due to transport from south to north and their more extensive equilibration with the atmospheric ${ }^{14} \mathrm{C}$. The oldest deep waters are found in the $\mathrm{CDW}(<-170 \%)$ and derive from the PDW. 
Table 2 CIVA 1 bomb ${ }^{14} \mathrm{C}$ inventories

\begin{tabular}{cccc}
\hline Station & $\begin{array}{c}\text { Surface total } \\
{ }^{14} \mathrm{C}(\% o)\end{array}$ & $\begin{array}{c}\text { Bomb }{ }^{14} \mathrm{C} \\
\text { inventories }^{\mathrm{a}}\end{array}$ & $10^{9}$ atoms per $\mathrm{cm}^{2 \mathrm{~b}}$ \\
\hline 6 & -97 & 1 & 4.9 \\
8 & -97 & 1.2 & 5.1 \\
12 & -117 & 0.8 & 2.4 \\
18 & -74 & 1.1 & 1.7 \\
24 & -83 & 1.8 & 3.1 \\
28 & -69 & 1.5 & 1.7 \\
38 & -52 & 4.7 & 4.7 \\
52 & 43 & 10.9 & - \\
\hline
\end{tabular}

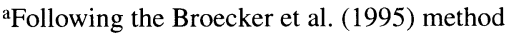

${ }^{b}$ Following the chlorofluorocarbon analogue strategy

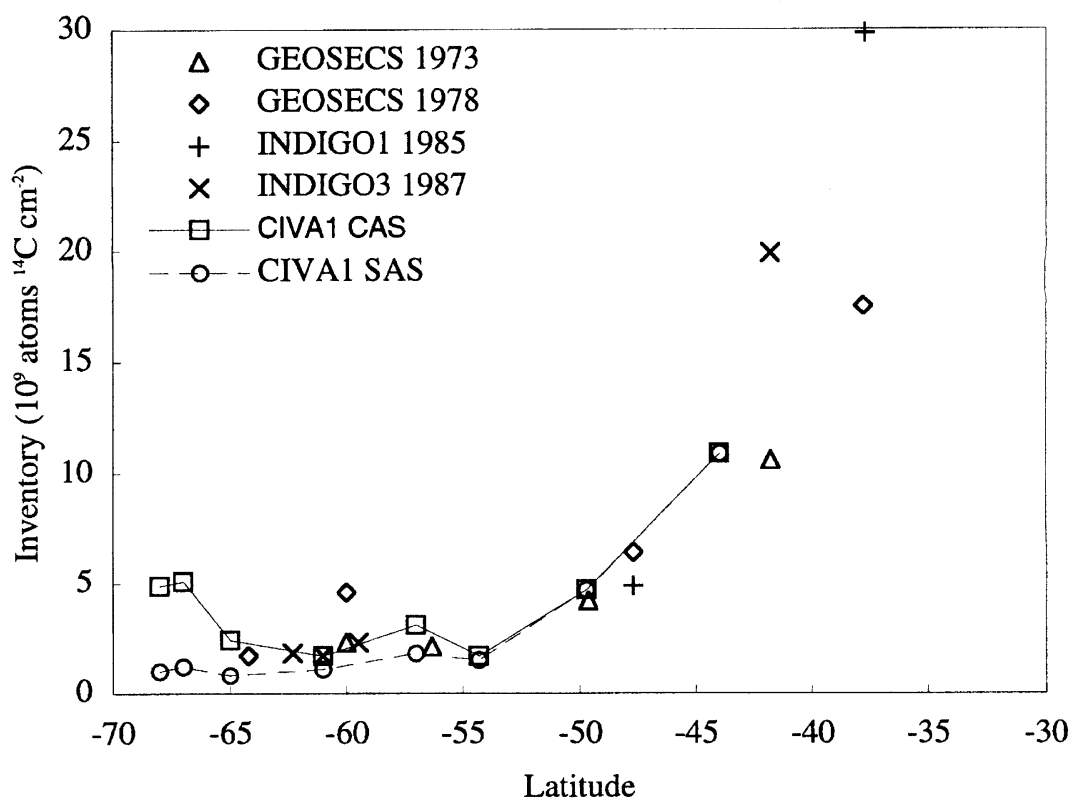

Figure 11 Bomb ${ }^{14} \mathrm{C}$ inventory versus latitude for GEOSECS, INDIGO3 and CIVA1 stations within $25^{\circ} \mathrm{W}-85^{\circ} \mathrm{E}$ and $70^{\circ} \mathrm{S}-30^{\circ} \mathrm{S}$.

Bomb ${ }^{14} \mathrm{C}$ has contaminated deep waters in the far south based on differences in measured ${ }^{14} \mathrm{C}$ between CIVA1 and GEOSECS and the CIVA1 distribution of CFC-11 and CFC-12. Our new CAS method relies on measured CFCs, a simple mixing model, and the established history of surface ocean ${ }^{14} \mathrm{C}$. A previously developed method, SAS from Broecker et al. (1995), relies on the assumption that all deep waters of the Southern Ocean are free of bomb ${ }^{14} \mathrm{C}$. For CIVA1 as well as other WOCE-era samples, such an assumption is invalid. In terms of bomb ${ }^{14} \mathrm{C}$ inventories, our new CAS methodology yields estimates identical to the SAS method for stations north of the PF, but substantially greater than SAS results when south of the PF (up to 5 times more when south of the ADZ). Although CAS offers an improvement for determining inventories south of PF, uncertainties remain high and are not ideal for validating ocean carbon-cycle models. CAS estimates in deep waters south of the PF would be improved if the history of surface ocean ${ }^{14} \mathrm{C}$ there were better constrained. South 
of the PF, we recommend that ocean modelers not concern themselves with inventories but rather with bomb and natural ${ }^{14} \mathrm{C}$ distributions (Fig. 4B,C), weighing errors accordingly. For CIVA1 north of the $\mathrm{PF}$, bomb ${ }^{14} \mathrm{C}$ is found in surface and intermediate layers; in the far south, bomb ${ }^{14} \mathrm{C}$ is found throughout the water column. Since GEOSECS, ${ }^{14} \mathrm{C}$ has decreased in surface waters (roughly the upper $200 \mathrm{~m}$ ) and has increased below, to as deep as $2000 \mathrm{~m}$ north of the PF.

The CIVA1 section began near Antarctica and was aborted prematurely at $44^{\circ} \mathrm{S}$ due to an emergency medical evacuation. Fortunately, the repeat section CIVA2 (February-March 1996) will allow the northern gap (where ${ }^{14} \mathrm{C}$ inventories should be greatest) to be filled in, once ${ }^{14} \mathrm{C}$ measurements are completed. The CIVA section along with other new WOCE ${ }^{14} \mathrm{C}$ data will greatly improve coverage in the Southern Ocean, a key area for ocean $\mathrm{CO}_{2}$ uptake. However, care will have to be exercised when estimating natural and bomb ${ }^{14} \mathrm{C}$ components so that ocean modelers will be able to take full advantage of this unique data set.

\section{ACKNOWLEDGMENTS}

For the variety of analyses required for this study, we thank E. Kaltnecker for help in measuring ${ }^{14} \mathrm{C}$, A. Dapoigny for help with ${ }^{3} \mathrm{H}$, D. Thouron at the Groupe de Recherche en Geodésie Spatiale (GRGS) for providing the CIVA1 $\mathrm{SiO}_{2}$ data, and J.-F. Tannau for help in building the degassing system. The CIVA1 cruise was supported by the Institut Français pour la Recherche et la Technologie Polaire (IFRTP). AMS ${ }^{14} \mathrm{C}$ measurements were supported by the CEA and CNRS. The contribution of JCO was supported by the Environment and Climate Programme of the EC (Contract ENVCT95-0132). This is LSCE Contribution $\mathrm{N}^{\circ} 110$.

\section{REFERENCES}

Andrié C, Jean-Baptiste P, Merlivat L. 1986. Tritium and Helium-3 in the northeastern Atlantic Ocean during the 1983 topogulf cruise. Journal of Geophysical Research 93:12511-24.

Archambeau A-S, Pierre C, Poisson A, Schauer B. 1998. Distributions of oxygen and carbon stable isotopes and CFC-12 in the water masses of the Southern Ocean at $30^{\circ} \mathrm{E}$ from South Africa to Antarctica: results of the CIVA1 cruise. Journal of Marine Systems 17:25-38.

Arnold M, Bard E, Maurice P, Duplessy J-C. $1987 .{ }^{14} \mathrm{C}$ dating with the Gif-Sur-Yvette Tandetron Accelerator: status report. Nuclear Instruments and Methods in Physics Research B29:120-3.

Bard E. 1988. Correction of AMS ${ }^{14} \mathrm{C}$ ages measured in planktonic foraminifera: paleoceanographic implications. Paleoceanography 3:635-45.

Bard E, Arnold M, Maurice P, Duplessy J-C 1987 Measurements of bomb radiocarbon in the ocean by means of accelerator mass spectrometry: technical aspects. Nuclear Instruments and Methods in Physics Research B29:297-301.

Bard E, Arnold M, Östlund HG, Maurice P, Monfray P, Duplessy J-C. 1988. Penetration of bomb radiocarbon in the tropical Indian Ocean measured by means of accelerator mass spectrometry. Earth and Planetary Science Letters 87:379-89.

Bayer R, Schlosser P. 1991. Tritium profiles in the Weddell Sea. Marine Chemistry 35:123-36.
Berkman PA, Forman SL. 1996. Pre-bomb radiocarbon and the reservoir correction for calcareous marine species in the Southern Ocean. Geophysical Research Letters 23:363-6.

Broecker WS, Peng TH. 1974. Gas exchange rates between air and sea. Tellus 26:21-35.

Broecker WS, Peng T-H, Östlund G, Stuiver M. 1985. The distribution of bomb radiocarbon in the ocean. Journal of Geophysical Research 90:6953-70.

Broecker WS, Sutherland S, Smethie W, Peng TH, Östlund G. 1995. Oceanic radiocarbon: separation of the natural and bomb components. Global Biogeochemical Cycles 9:263-88.

Carmack EC, Foster TD. 1977. Water masses and circulation in the Weddell Sea. In: Dunbar MJ, editor. Polar oceans. Calgary: Arctic Institute of North America. p 151-65.

Foster TD, Carmack EC. 1976. Frontal zone mixing and Antarctic bottom water formation in the southern Weddell Sea. Deep-Sea Research 23:301-17.

Gordon AL. 1971. Antarctic polar front zone. In: Reid JL, editor. Antarctic Oceanology I, Antarctic research series. Washington: American Geophysical Union. p 205-21.

Haine TWN. 1996. Combining passive tracer observations with ocean circulation models. International WOCE Newsletter 23:3-5.

Jean-Baptiste P, Mantisi F, Mémery L, Jamous D. 1991. 
${ }^{3} \mathrm{He}$ and chlorofluorocarbons (CFC) in the Southern Ocean: tracers of water masses. Marine Chemistry 35:137-50.

Jenkins WJ. 1980. Tritium and ${ }^{3} \mathrm{He}$ in the Sargasso Sea. Journal of Marine Research 38: 533-69.

Key RM, Quay PD, Jones GA, McNichol AP, Von Reden KF, Schneider RJ. 1996. WOCE AMS Radiocarbon I: Pacific Ocean results (P6, P16, P17). Radiocarbon 38(3):425-518.

Maier-Reimer E. 1993. Geochemical cycles in an ocean general circulation model preindustrial tracer distributions. Global Biogeochemical Cycles 7:645-77.

Mensch M, Bayer R, Bullister JL, Schlosser P, Weiss RF. 1996. The distribution of tritium and CFCs in the Weddell Sea during the mid-1980s. Progress in Oceanography 38:377-415.

Orr JC. 1996. The ocean carbon-cycle model intercomparison project of IGBP/GAIM. In: Ormerod B, editor. International Energy Agency, ocean storage of $\mathrm{CO}_{2}$ workshop 3: international links and concerns (ISBN 189837304 3). Southampton, England.

Orsi AH, Nowlin WD, Whitworth T III. 1993. On the circulation and stratification on the Weddell Gyre. DeepSea Research 40:169-203.

Orsi AH, Whitworth T III, Nowlin WD. 1995. On the meridional extent and fronts of the Antarctic Circumpolar Current. Deep-Sea Research 42:641-73.

Östlund HG, Grall C. 1988. INDIGO 1985-1987 Indian Ocean radiocarbon: tritium laboratory data report. University of Miami: Rosenstiel School of Marine and Atmospheric Science.

Östlund HG, Stuiver M. 1980. GEOSECS Pacific radiocarbon. Radiocarbon 22(1):25-53.

Poisson A, Chen C-TA. 1987. Why is there little anthropogenic $\mathrm{CO}_{2}$ in the Antarctic bottom water? Deep-Sea Research 34:1255-75.

Sarmiento JL, Orr JC, Siegenthaler U. 1992. A perturbation simulation of $\mathrm{CO}_{2}$ uptake in an ocean general circulation model. Journal of Geophysical Research 97: $3621-45$.

Schlosser P, Bullister JL, Bayer R. 1991. Studies of deep water formation and circulation in the Weddell Sea using natural and anthropogenic tracers. Marine Chemistry 35:97-122.

Schlosser P, Kromer B, Weppernig R, Loosli HH, Bayer R, Bonani G, Suter M. 1994. The distribution of ${ }^{14} \mathrm{C}$ and ${ }^{39} \mathrm{Ar}$ in the Weddell Sea. Journal of Geophysical Research 99:10275-87.
Stuiver M, Östlund HG. 1980. GEOSECS Atlantic radiocarbon. Radiocarbon 22:1-24.

Stuiver M, Östlund HG. 1983. GEOSECS Indian Ocean and Mediterranean radiocarbon. Radiocarbon 25(1): $1-29$.

Stuiver M, Östlund HG, McConnauqhey TA. 1981. GEOSECS Atlantic and Pacific ${ }^{14} \mathrm{C}$ distribution. In: Bolin B, editor. Carbon cycle modeling. New York: John Wiley \& Sons. p. 201-9.

Stuiver M, Polach HA. 1977. Reporting of ${ }^{14} \mathrm{C}$ data. $R a$ diocarbon 19(3):355-63.

Taylor NK. 1995. Seasonal uptake of anthropogenic $\mathrm{CO}_{2}$ in a ocean general circulation model. Tellus 47B:14569.

Toggweiler JR, Dixon K, Bryan K. 1989a. Simulations of radiocarbon in a coarse-resolution world ocean model. 1. Steady state prebomb distributions. Journal of Geophysical Research 94:8217-42.

Toggweiler JR, Dixon K, Bryan K. 1989b. Simulations of radiocarbon in a coarse-resolution world ocean model. 2. Distributions of bomb-produced carbon 14. Journal of Geophysical Research 94:8243-64.

Toggweiler JR, Samuels B. 1993. New radiocarbon constraints on the upwelling of abyssal water to the ocean's surface. In: Heimann, M, editor. The global carbon cycle. Berlin: NATO ASI Series. p 333-66.

Toggweiler JR, Wallace D. 1995. Transport capacity for passive tracers. US WOCE Report 1995. p 36-8.

Warner MJ, Weiss RF. 1985. Solubilities of chlorofluorocarbons 11 and 12 in water and seawater. Deep-Sea Research 32:1485-97.

Weiss RF, Östlund HG, Craig H. 1979. Geochemical studies of the Weddell Sea. Deep-Sea Research 26A: 1093-120.

Weppernig R, Schlosser P, Khatiwala S, Fairbanks RG. 1996. Isotope data from Ice Station Weddell: implications for deep water formation in the Weddell Sea. Journal of Geophysical Research 101:25723-39.

Whitworth T III, Nowlin WD. 1987. Water masses and currents of the southern ocean at the Greenwich Meridian. Journal of Geophysical Research 92:6462-76.

Worthington LV. 1977. The case for near-zero production of Antarctic bottom water. Geochimica Cosmochima Acta 41:1001-6.

Wunsch C, Hu DX, Grant B. 1983. Mass, heat, salt, and nutrients fluxes in the South Pacific Ocean. Journal of Physical Oceanography 13: 725-753. 


\section{APPENDIX: VENTILATION MODEL}

Our ventilation model is inspired by Jenkins (1980) who used such a model to explain the penetration of ${ }^{3} \mathrm{H}$ in the North Atlantic and to study the ${ }^{3} \mathrm{H} /{ }^{3} \mathrm{He}$ relationship. At any time t, our model determines the annual ventilation rate $\eta$, which is defined as the fraction of water at depth $\mathrm{z}$ replaced by water originating from the surface during the timestep $\Delta \mathrm{t}$. A time-lag $\tau$ is defined to correspond to the travel time of a water parcel moving from the surface to depth $\mathrm{z}$. Thus, at depth $\mathrm{z}$

$$
\mathrm{C}_{\mathrm{z}, \mathrm{t}+1}=\mathrm{C}_{\mathrm{z}, \mathrm{t}}+\eta \times\left[\mathrm{C}_{0,(\mathrm{t}-\tau)}-\mathrm{C}_{\mathrm{z}, \mathrm{t}}\right]
$$

where $\mathrm{C}_{0,(\mathrm{t}-\tau)}$ is the surface concentration at time $(\mathrm{t}-\tau)$ and $\mathrm{C}_{\mathrm{z}, \mathrm{t}}, \mathrm{C}_{\mathrm{z}, \mathrm{t}+1}$ are the concentrations at depth $\mathrm{z}$ in years $\mathrm{t}$ and $\mathrm{t}+1$.

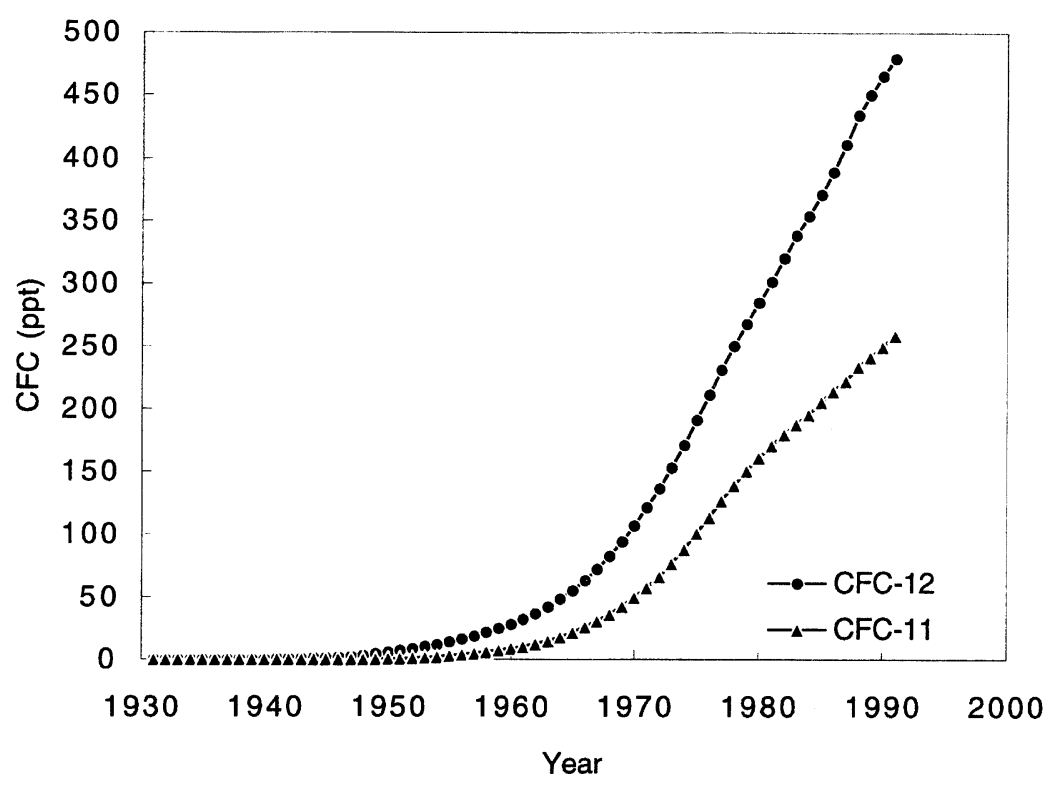

Figure A1 Partial pressure of atmospheric CFC-11 and CFC-12 in the Southern Hemisphere versus time (Walker, Salameh, and Weiss, personal communication 1995).

First, the annual ventilation rate and the transit time are adjusted using both CFC-11 and CFC-12 to match the measured concentrations at the time of CIVA1 (1993). For our calculations, we used the time evolution of atmospheric CFC-11 and CFC-12 concentrations (Fig. A1) given by Walker, Salameh, and Weiss (personal communication 1995) as well as solubilities from Warner and Weiss (1985). This simple method gives the best result when a transit time $\tau$ of $<1 \mathrm{yr}$ is chosen. Results are essentially identical whether using CFC-11 or CFC-12. With our method $(\Delta t=1 \mathrm{yr})$, this means that $\tau$ is set to zero.

Second, we used the same model, now with the known $\eta$ and $\tau$ from the CFC calibration, and a reconstructed ${ }^{14} \mathrm{C}$ input function shown in Figure A2, to determine the evolution of the total ${ }^{14} \mathrm{C}$ until the time of CIVA1 (see an example of the method in Fig. A3). For this, we again used equation (A1), where $\mathrm{C}$ is now ${ }^{14} \mathrm{C}$. The reconstructed ${ }^{14} \mathrm{C}$ input function has large uncertainties due to the scatter of available data (Fig. A3). We have arbitrarily drawn minimum and maximum curves. We favor the lowest curve because it allows a close agreement around the transition at $90 \mu \mathrm{mol} \mathrm{kg}^{-1}$ 
between the CAS and SAS methods; SAS is applied for waters where $\mathrm{SiO}_{2}$ lies between 0 and 90 $\mu \mathrm{mol} \mathrm{kg} \mathrm{kg}^{-1}$.

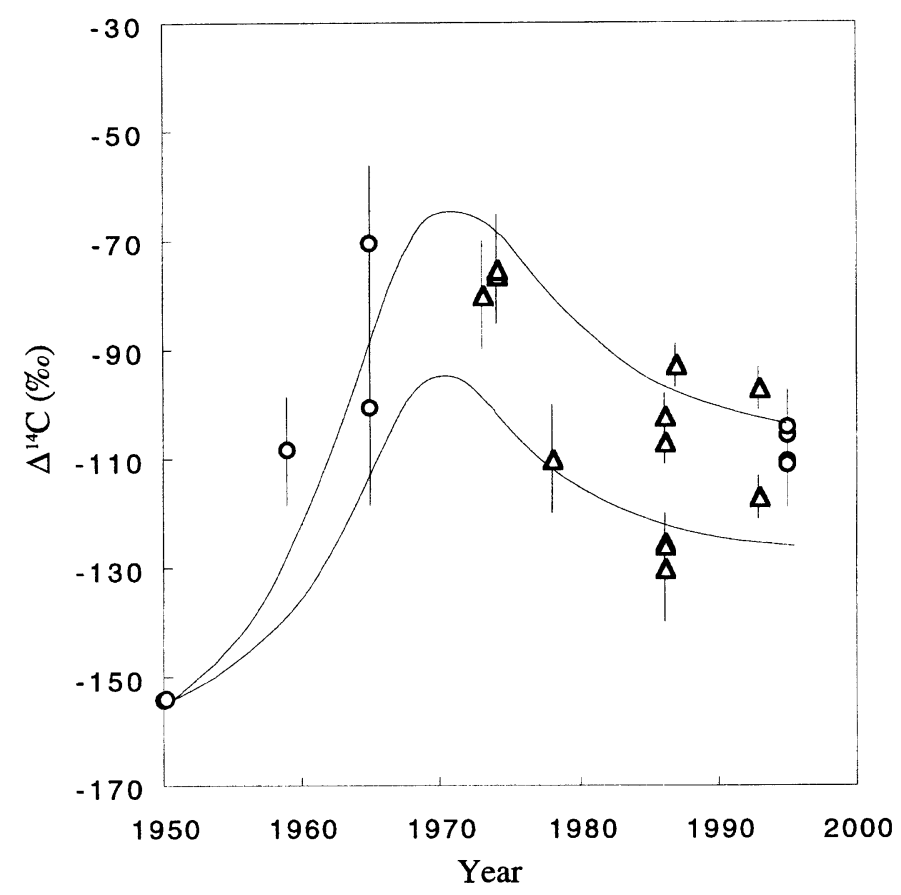

Figure A2 Time evolution of the surface ocean $\Delta^{14} \mathrm{C}$ compiled from the ${ }^{14} \mathrm{C}$ record from marine molluscs, brachiopods, echinoderms and foraminifera $(\mathrm{O})$ collected near the Antarctica (Berkman and Forman 1996), and ${ }^{14} \mathrm{C}$ measurements on surface samples from GEOSECS, INDIGO3 and CIVA1 stations $(\triangle)$ near Antarctica (Östlund and Stuiver 1980; Stuiver and Östlund 1980, 1983; Stuiver et al. 1981; Schlosser et al. 1994; Östlund and Grall 1988). Predicted prenuclear surface $\Delta^{14} \mathrm{C}$ is ca. $-150 \%$ o (Berkman and Forman 1996). Minima and maxima curves are drawn arbitrarily. We chose the lower curve for our CAS methodology because with it CAS and SAS methods agree for waters where $\mathrm{SiO}_{2}<90 \mu \mathrm{mol} \mathrm{kg}{ }^{-1}$. 


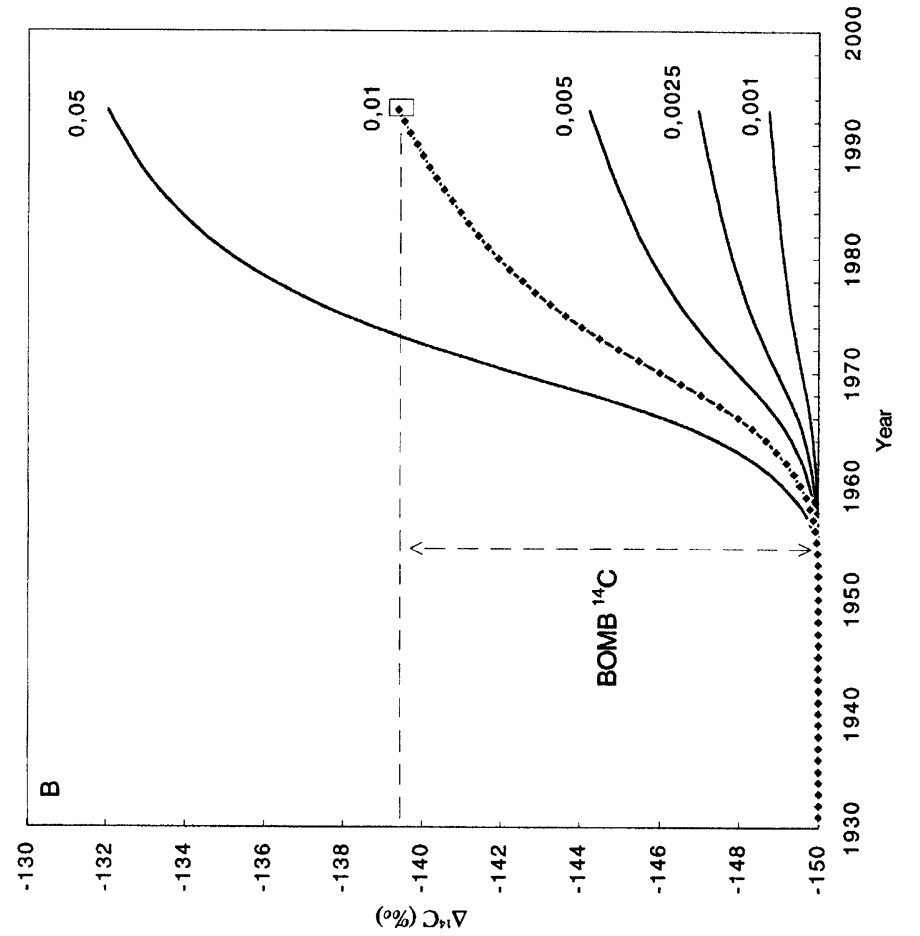

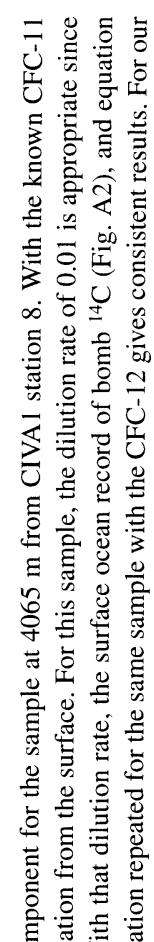

(\%) $D_{n} \nabla$

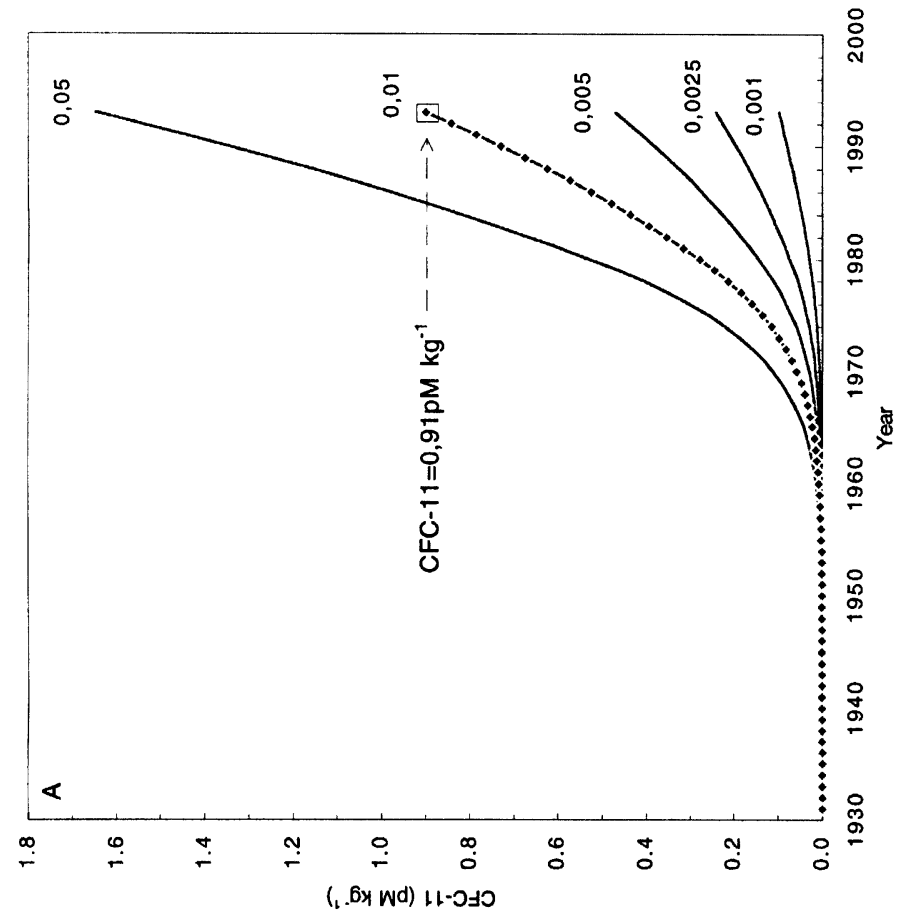

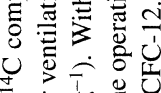

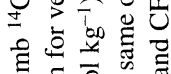

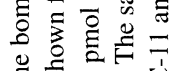

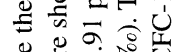

密实

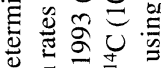

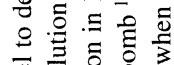

